\title{
SPACES OF EXCLUSION? EXPLORING THE EVERYDAY PUBLIC SPACES IN ST. JAMES TOWN
}

\author{
by
}

Naomi Arsenault, BA Honours in Social Cultural Anthropology, University of Toronto, 2007

\author{
A Major Research Paper \\ presented to Ryerson University \\ in partial fulfillment of the requirements for the degree of \\ Master of Arts \\ in the program of \\ Immigration and Settlement Studies
}

Toronto, Ontario, Canada, 2011

CNaomi Arsenault 
I hereby declare that I am the sole author of this major research paper.

I authorize Ryerson University to lend this paper to other institutions or individuals for the purpose of scbolarly research.

$$
\text { A }
$$

I further authorize Ryerson University to reproduce this paper by photocopying or by other means, in total or in part, at the request of othex institutions or individuals for the purpose of scholarly research. t 


\title{
SPACES OF EXCLUSION? EXPLORING THE EVERYDAY PUBLIC SPACES IN ST.
} JAMES TOWN

\author{
Naomi Arsenault \\ Master of Arts, 2011 \\ Immigration and Settlement Studies \\ Ryerson University
}

ABSTRACT

The purpose of this research paper is to explore how public spaces in low-income, high-density neighbourhoods may be utilized to encourage social cohesion. Toward that goal, St. James Town - an inner city neighbourhood of Toronto - was chosen as the case study. Most residents in SJT are immigrants from non-traditional sources, and a high proportion of them have arrived in Canada within the last five years. Based on their age and educational qualifications, it may seem that the residents of SJT should be a part of Toronto's "Creative Class", yet, their employment and housing conditions reveal a contrasting story. Living in residual housing, earning less than the Toronto average, and having little interaction with their neighbours in public spaces, severely thwarts their functional and subjective integration into the host society. As a result, SJT residents remain one of the major marginalised groups in Toronto.

Key Terms: functional integration, subjective integration, social cohesion, public space, creative class 


\section{Acknowledgements}

I want to acknowledge the support and encouragement of everyone who has helped me throughout this past year. In particular, I wish to extend my sincere appreciation to:

My supervisor, Dr. Sutama Ghosh, for her patience and guidance throughout the research and writing process. I thank her for challenging and inspiring me to write a major research paper that I can look back on with pride.

Dr. Vappu Tyyskä, for not only her help as a second reader, but also for her encouragement, understanding and flexibility throughout this process.

The residents of St. James Town, and the research participants themselves - thank you for sharing your time and opinons with me.

To my family and friends:

I thank my parents for their unconditional love and support; to my father, Claude and my step-mother, Susan, for the unique perspectives they have blessed me with; my mother, Patricia for her dedication to my MA and for the incredible amount of time she contributed to editing my paper, and for my step-father, Thomas's, patience and support to my mother and I.

To all the kindred spirits and friends who have shared their love and energies with me.

Finally to my partner Devon Hamilton and his mother Louise Goulet who constantly reminded me of the importance of moving forward. 
Table of Contents

I. Introduction 1

II. A Brief Review of Factors Contributing to the Current Conditions of Public Space in

. Economically Marginalized High-Rise Neighbourhoods 6

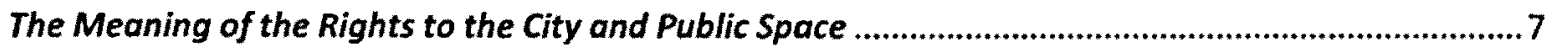

The Physical State of Housing in Toronto and its Effect on Marginalized Segments of Society..........13

How Discrimination Effects Individuals' Sense of Belonging .................................................. 14

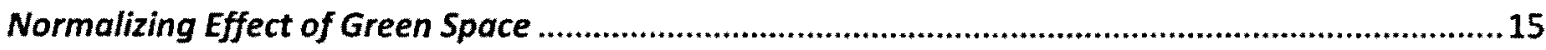

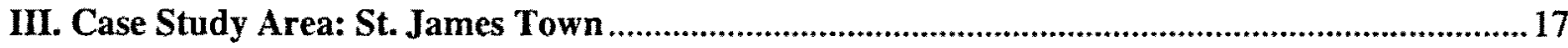

Socio-Economic and Demographic Conditions of the People Living in SJT......................................19

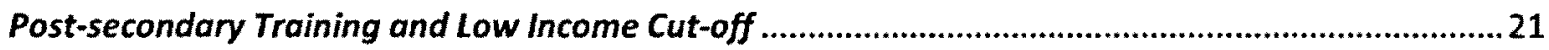

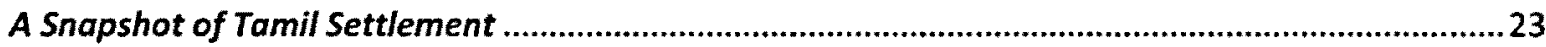

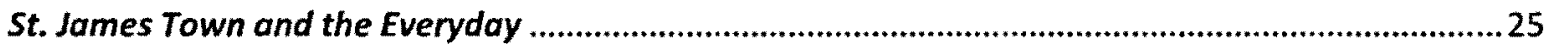

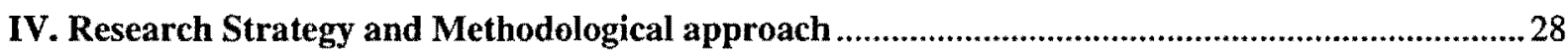

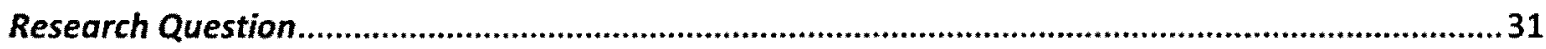

V. Subjective Integration and the Spaces and Places of Exclusion and Inclusion ............................33

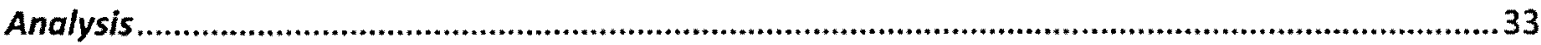

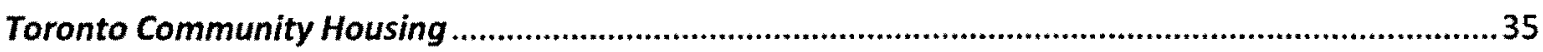

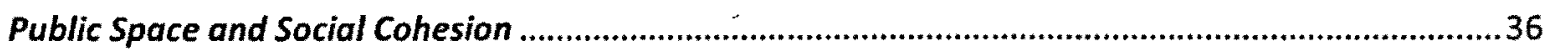

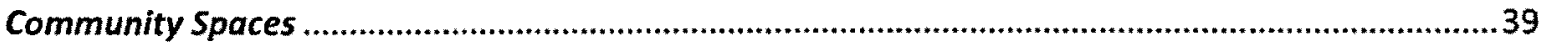

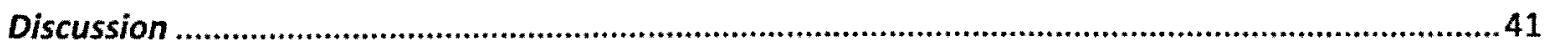

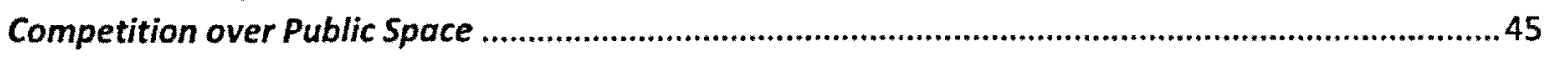

VI. Conclusion and Suggestions for Future Usages of Public Space ................................................ 47

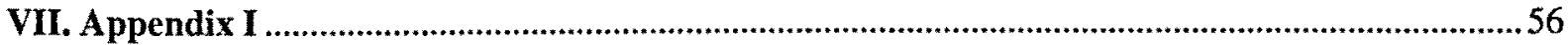

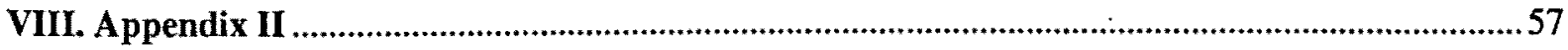

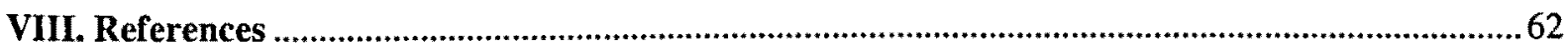




\section{Introduction}

The tradition of valorizing profits over people is an intriguing issue, far too complex to uncover in this short paper. Therefore, I wish to explore a tangible manifestation arising from this valorization: housing treated as a commodity as opposed to a basic human right. This is an inquiry into everyday experiences of economically marginalized individuals living in high-rise neighbourhoods where a high percentage of residents are newer immigrants to Canada, particularly racialized minorities. Many people in these neighbourhoods tolerate unfair realities resulting from society's unequal system of wealth redistribution (Midgley, 1999) and other societal exclusions.

When trying to understand the current reality of any society it is important to gain an understanding of the political and economic trends affecting the everyday lives of people. Toronto, like many cities around the world, is following Richard Florida's (2002) creative class thesis (Peck, 2005), in order to gain economic prosperity and status. Florida (2002) advises that a great percentage of municipal resources be dedicated toward attracting the best of the Creative Class in order to gain and maintain a competitive edge. According to Florida (2005), at the core of the new dominant class, the creative class, are individuals whose economic function is to create new ideas and new technology. The broad definition of the creative class includes scientists, engineers, artists, cultural creatives, managers, professionals, and technicians (p.272).

The creative class thesis (Florida, 2002) claims that the secret to economic prosperity is in the following three T's: Technology, Talent and Tolerance. He suggests that this combination will maximize creativity's potential, leading to exponential economic growth (Florida, 2005, p.37). This happens in a context where globalization of the economy has grown sharply and 
cities have become exceedingly centered on attracting global capital, while at the same time generating contradictory spaces (Sassen, 2006). Major urban hubs contain a disproportional share of the disadvantaged and become principal sites of income polarization (Ibid).

This contradiction is felt by numerous migrants, many of whom possess the level of postsecondary education required to become part of the creative class. These individuals have selected Canada as a destination they desire to immigrate to, with the idea that they will contribute their skill and knowledge to Canadian society. Despite their education, skills and knowledge, many immigrants are faced with barriers that prevent them from exercising these skills and creative potentials (Alboim, 2005). Toronto, as a participant in the three T's system (Florida, 2002) - a city-planning formula municipalities utilize in order to gain economic prosperity - does attract new residents. However, because the Creative City does not place the eradication of inequality or poverty as a precedent, many people are forced to exhaust their creativity finding ways to survive in a very expensive city.

Many immigrants who have selected Toronto as a new home and who have been accepted because of their possession of required Canadian immigration criteria, such as postsecondary training or certain employment experience, are faced with many difficulties, despite having belonged to the creative class in their former home (Alboim, 2005). Some of these problems are the result of exclusion from wider society, such as finding suitable housing or employment (lbid). As this paper will discuss in more detail, many of these newcomers to Canada find themselves living in deteriorating, high-rise apartment buildings, with limited places to socialize and share their creative energies. 
It is essential to understand the everyday lives of newcomers because, as discussed in Andy Merrifield's (2006), Henri Lefebvre: A Critical Introduction, “...Everyday life is a primal arena for meaningful social" (p.10). In order to change life or invent a new society, where true social cohesion exists and all members have full rights to the city, one must examine the concrete realities on the level of everyday lives, or what is called the lived experiences of regular people (p.10). My interpretation of social cohesion is framed by Frideres' (2008) perspective, outlined in the chapter, Creating an Inclusive Society: Promoting Social Integration in Canada, in which he describes social cohesion as characterizing an integrated society (p.79). Social cohesion can be defined from the perspective of either a group or an individual (Ibid). The essence of the term refers to mutual interactions between treatment and adaptation of newcomers and native-born Canadians. Social cohesion focuses on the social contacts and group memberships of individuals. However, one must ask, are these contacts and memberships primarily within an ethnic group, a non-ethnic group or combination of the two (Ibid)? One must also question the relevance of asking between whom the contracts and memberships are if an individual or group feels like a member of the society.

Another way of putting this is, as Murdie and Ghosh (2010) ask, "Does spatial concentration necessarily equate with lack of integration?" (p.295). Subjective integration, functional integration and civic integration are important to consider when discussing the extent to which immigrants are able to achieve their needs and fulfill their interests in a new country (Murdie and Ghosh, 2010, p.296). Short-term objectives, such as housing, language, education and employment concerns are considered to be part of functional integration (Ibid), while longterm objectives such as citizenship and civic participation are considered to be civic integration (Ibid). Subjective factors, which well planned public space (common spaces inside and outside of 
the high-rise apartments) can affect, are concerned with issues such as identification with the new country, internalization of its values and norms, and satisfaction with the overall immigration and settlement process (Ibid).

Social cohesion represents the following: "Absence of exclusions and marginalization, and a contrast between a sense of belonging versus isolation, participation versus nonengagement, recognition versus rejection and legitimacy versus illegitimacy" (Jenson, 1998, in Galabuzi and Teelucksingh, 2010, p.2). Therefore, in order to make inclusive society a reality in a city such as Toronto, it is important to look at the everyday experiences of newcomers, and to examine what is happening at the neighborhood level, or outside of the high-rise that is now called home. One must begin at a basic level of societal interaction - the communication and exchange between neighbors, especially relevant in high density neighborhoods, where many newcomers to Canada begin their housing careers. These environments are spaces of continuous contact between residents, inside and outside of their apartment buildings, even if this contact is indirect, such as sharing an elevator without formal acknowledgement of one another, or seeing one another on a daily basis as their children play in the park, yet not conversing.

This paper aims to examine how public space in low-income, high-density environments may be utilized to encourage social cohesion between neighbors. Public or common space will be used throughout this paper as a connotation for every space that is outside of an individual's private apartment unit. Therefore, the following is defined as public space: green space outside of the apartment buildings, including parks, gardens, playgrounds, fields, basketball courts, swimming pools, community centers, indoor stairwells, hallways, community rooms, and building laundry rooms. This paper examines how residents of the study area, St. James Town, 
census tract 0065.00 (discussed in more detail in section III), see and use the public spaces of their neighborhood. Both quantitative and qualitative research methods were utilized for exploring the topic of this paper; data from census tract 0065.00 was analyzed as well as face to face interviews conducted with residents of St. James Town. Part of this exploration will attempt to gain an understanding of how a subjective sense of belonging strengthened at the neighborhood level, assists with newcomers' integration into wider Canadian society. 


\section{A Brief Review of Factors Contributing to the Current Conditions of Public Space in Economically Marginalized High-Rise Neighbourhoods}

Attracting global capital is done through inter-city competition, which places more importance on certain urban spaces that will attract high-income groups and tourists (Ronneberger, 2008, p.143), neglecting the high-density places that house the large supply of labour or the majority of urban residents (Sassen, 2006). Florida (2002) defines the difference between the creative class and the working and service class as follow: "The working and service class are primarily paid to execute according to plan, while those in the creative class are primarily paid to create and have more autonomy and flexibility than the other two classes" (p.8). However, as Peck (2005) discusses, the creativity thesis has little concern with the economically marginalized segments of society. People living on the low side of income polarization are portrayed as, "servants of the creative class or the stranded inhabitants of hopeless cities" ( $p$ 15).

Peck sees Florida's (2002) thesis as a creative way to justify market distribution while minimizing the importance of redistributing wealth in a fair and equal way. His vision appears to be aligned with a low-tax, market-oriented polity (Peck 2005, p.15). In fact, there is not much regard for those who are on the fragile side of the labour markets, beyond the suggestion that perhaps one day these individuals, through acts of sheer creative, might be lifted into the new overclass (Ibid). Therefore, city planning often excludes many members of society in favour of attracting members of the creative class.

The internationalization of labour is a direct result of globalization, as people follow capital in order to improve their quality of life (Dikec and Gilbert, 2002, p.8). The migration of people through immigration has been for the most part concentrated in cities. Therefore, cities 
have become increasingly heterogeneous and diverse (Dikec and Gilbert, 2002, p.8). It should be seen as common sense that in this globalized market economy, people will have to move around and that an individual's membership in a city should automatically provide rights to participate in all aspects of the urban situation in which she or he resides. However, while freedom has been granted to the movement of goods and capital, people face barricades which challenge their right to the city, and their freedom in utilizing and designing public spaces within these cities (Boudreau J, Keil R, Young D, 2009). Many of these barricades and challenges affect the integration of residents within their new city.

\section{The Meaning of the Rights to the City and Public Space}

The city is ideally conceived of as an entity which is public, comprised of many different social and economic factors, so the right to the city "becomes a claim upon a society for resources necessary to meet the basic needs and interests of members rather than a kind of property that some possess and others do not" (Lefebvre, quoted in Dikec and Gilbert, 2002, p.15). The right to the city can then become conceived as an aspect of being human and the right to proper accessibility of the city's amenities, rather than as an inherent quality that some individuals are entitled to while others are not (Ibid).

Mitchell's (2003) discussion of public space and social justice, which is written with a Marxist lens, explains how Lefebvre views the city and the role of difference. Cities, unlike the privacy, homogeneity and isolation that characterize rural life, were built on spaces of public and social interactions and exchanges between people who were different, including their preferred lifestyles and countries of origin. Therefore, the public implies heterogeneity and the space of the city with its business and constant attraction of newcomers, assures this interaction with 
difference. However, in order for this interaction with difference to succeed, all people must feel included and be allowed to affect change in the city (Harvey, 2003). This right has always been struggled for by various groups and individuals, although the majority of the time it is the people who have secured a dominant position in society and who work to continue this replication of dominance by excluding others, who win the struggle (Mitchell, 2003, p.18).

For Lefebvre, these rights are not tied to the nation, such as those of voting and paying taxes; the right to the city entails the following rights: to information, to expression of ideas, to culture, to identity in difference and equality, and to the city and its service (Dikec and Gilbert, $2002, p .17)$. These entitlements affirm for the users the right to make known their ideas on the space and time of their activities in the urban area (Ibid). In order for these entitlements to be actualized there is a need for major changes in the structural dynamics that produce urban space (Ibid). Unless the forces of the supposed free market, which dominate and shape to a large extent urban space, are modified, the right to the city will remain an impossible ideal for those who cannot bid for the dominated spaces of the city (Ibid).

Mitchell (2003) traces the notion of urban public space to the Greek agora, an open space where public affairs and legal disputes were conducted by those people considered citizens (p.131). While the agora was a political space, it was also a market-place; at the same time commerce was conducted, so too were entertainment and political decision-making (Ibid). The agora provided a meeting place for strangers, whether they were citizens, buyers or sellers - this was the first vision of public space. In this space one would expect to hear from social perspectives, experiences and affiliations that were different from one another. This idea of space is embodied in urban experiences and is defined by the conflicting demands for the right to the 
city (Ibid). Public space is the material location where unmediated social interactions and public activities of all members of the public take place, so public space is the space of the public (Ibid). However, this description is an ideal of public space in democracies and the function of this space has rarely lived up to this vision. The difficulty lies with who is considered to be the public and where the space for the public is (Ibid).

Mitchell (2003) emphasizes that throughout history, whether in the Greek agora or $18^{\text {th }}$ century German coffeehouses or in the streets or parks of the city, these places have never been simply free spaces of unmediated interaction - there has always been someone excluded (p.131132). The composition of the public in these spaces was carefully selected and homogenous, consisting of those with power, legal standing and a desired respectability (p.132). Only certain people had the right to citizenship; immigrants, women, and racialized minorities may have been welcomed to spend money or to offer their labour, but their political input was not accepted, resulting in the denial of their full participation in society (Mitchell, 2003, p.133). The construction of the public realm has been built on the idea of having access to a private dwelling, where one has the choice to retreat to private from public or vice versa (lbid). The public sphere in capitalist democracies was understood, and injected into contemporary normative understanding, as a voluntary community of private individuals who normally owned property, forming what was constituted as the citizenry (Ibid). Excluded from this citizenry, by customs, economics, franchise, law and sometimes physical force were women, non-white men and those without property (Ibid).

However, this exclusiveness has been and continues to be contested and has become a rallying point for successive waves of political activity (Mitchell, 2003, p. 132) Women and 
people of color have won entrance to the public, demanding the right to be seen, to be heard, and to directly influence the state and society (Ibid). These struggles and protests have been brought to public places in ways that some of dominant society considered unlawful and unruly; however, the opposition has resulted in increased awareness for social justice (Mitchell, 2003).

Mitchell (2003) continuously calls for people, who may consider themselves different from one another, to mobilize and interact in the streets and public spaces of the city. The politics of difference celebrates the distinctive cultures and characteristics of different groups (Valentine, 2001, p.136). This mobilization should demand an increase in quality of life and the inclusion of their rights in the decisions concerning the spaces they occupy and the cities they live in. However, the discourse of order and security of public spaces is constantly watering down the potential for social inter-connectedness and mobilization. The contradiction found in the discussion of public space and democracy is that it demands a certain disorder and unpredictability to function as a democratic public space; yet democratic theory advocates a certain order and rationality as essential to the success of democratic dialogue (Mitchell, 2003, p. 130).

As Valentine (2001) reminds us, a space from the body to the nation is imbued with certain meanings (p.8). These meanings shape the way these spaces are produced and used and in turn how the use of these spaces loops back into shaping the way in which people categorize others and identify themselves (Ibid). The ideology of the unsafe street, a place of unpredictability and spontaneous violence (Valentine, 2001, p. 170), a representation often associated with aged, inner-city, high-rise neighbourhoods, acts as a barricade to social cohesion. People adapt survival tactics they find suitable for different environments, often involving 
protecting personal space and body through avoiding interaction with "other" unknown people (Ibid). However, as part of this tactic or the development of living in close proximity over time, certain communities and networks are formed, in which neighbours mobilize to help one another (Ghosh, 2010).

Many of the current residents of high-rise neighbourhoods are newcomers from various continents; however, the physical structure of the buildings and space were built in a way that limits the social interaction between neighbours. Despite these barricades, residents transform the functional spaces into places they can call "home away from home" (Ghosh, 2010, p.1). It is also important to discover ways to create and build the public spaces in these neighbourhoods so that social cohesion is encouraged. This process will be more effective if residents feel integrated enough to see themselves as entitled to do as they desire, so long as they are not harming others who use the space.

The marginalized space between the high rises of this neighborhood and the common spaces inside the buildings, not including the residents' apartments, will be included for the purpose of this paper with what Banerjee (2001) refers to as the domain of the public sphere, "which is seen to exist between the privacy of the individual and domestic life and the state (or the government)" (p.14). The definition of the public sphere will be expanded for this topic, as the following: anything outside of a resident's private apartment unit, as well as outside of the private economic sector, will be considered the public sphere. Madanipour (2004) discusses the significance that these marginalized public spaces have for encouraging social integration, if utilized and designed properly. 
Much of what was and often still is considered public space in the inner city, are spaces that are either not well cared for or have not been designed for people to actually utilize (Mitchell, 2003, p.21), and does not serve as an attractive space or functional place for residents to engage or socialize in. The right to housing, the right to inhabit the city, requires more than a roof over one's head; it demands the redevelopment of the city in a manner that meets the needs, desires and pleasures of its inhabitants, especially those who are marginalized (Ibid). A mobilization among the people of the city is needed in order to actualize this vision, especially as the state is in transition from the welfare state and the public provision of social infrastructure to the prioritization of urban space designed and marketed for residents with a disposable income and leisure time (Ronneberger, 2008, p.142).

Ghosh (2010) states that in the Toronto Census Metropolitan Area (CMA), high-rise residential buildings comprise about $27 \%$ of the total housing stock (Statitics Canada, 2006, in Ghosh, 2010, p.1). This includes more than one thousand high-rise apartment buildings, between eight and twenty-nine storeys, mostly constructed in the 1960's and 70's (Ibid). The mass produced high-rise rental buildings were developed to look like ordered, regimented places, ignoring the everyday practices and needs of people living there (Ibid). At time of construction many of these buildings were built for middle-class singles and couples, who were envisioned to move out as their economic condition improved (Ibid). However, since the early 1990 's and as a result of increased volumes of international migration to the city, high-rise neighbourhoods became ethno-racially more diverse (Ghosh, 2010, p.2). Increasing demands for low-cost rental units and a socially-induced scarcity of housing supply, as well as a precarious labour market, have put many immigrants in a vulnerable state (Ibid). 


\section{The Physical State of Housing in Toronto and its Effect on Marginalized Segments of Society}

It is important to point out that people entering Canada as economic, family or refugee class immigrants will often possess higher education; however, this may not be valued by Canadian society (Alboim, 2005). The Toronto region has pockets of high rise neighbourhoods where concentrations of economically marginalized Indians, Pakistanis, Caribbean and African blacks, and white immigrants from Eastern Europe are found (Quadeer, 2003). The ethnic concentrations coincide with both poverty of neighbourhoods and poor quality of housing, maintained by the continuing demands of new tenants searching for affordable housing, which is in short supply in the region (Israelite, et al, 1999; Quadeer, 2003). One last point to be raised, as articulated by Quadeer (2003), is that the risk of being marginalized is particularly high if ethnic segregation is combined with low incomes and poverty. This marginalization may increase if there is a lack of public spaces that encourage empowerment and inclusiveness among the residents.

Marcuse (2006) uses the term tenement city to describe neighbourhoods characterized by cheaper single-family areas, usually high-rise apartment rentals, occupied by lower-paid workers and generally including social housing. Marcuse discusses the tenement city as part of city planning where a city is composed of different residential quarters where residents are lumped together based on different criteria, such as in a working-class, high-rise neighbourhood. However, as Murdie and Ghosh (2010) demonstrate with the housing experiences of Bangladeshis in Canada, it becomes obvious that immigrant class and housing experience is not as simple as Marcuse (2006) explains. One of Canada's most recent immigrant groups, Bangladeshis, have arrived under the immigration category of economic migrant, highly fulfilling the status of designer migrants by meeting the immigration selection criteria of being young, well educated and with professional 
skills (p.304). Unfortunately, despite meeting all the important criteria, Bangladeshis are among Toronto's most impoverished ethnic groups, constituting one of the most residentially segregated groups in Toronto. Most of the Bangladeshi communities are in low-income, high-rise neighbourhoods (Ibid).

\section{How Discrimination Effects Individuals' Sense of Belonging}

Hiebert (2009) found that there was a pattern of a number of groups having consistent problems in their housing careers, which points to issues of discrimination within dominant Canadian society. Hiebert's research demonstrates that the groups in Canada who consistently felt the impacts in the lack of affordable housing and crowding were refugees and immigrants identifying as black, Arab and West Asian (Ibid).Unfortunately, this research also demonstrates that not everyone who enters the country under the same immigration category (economic, business or family class, refugees) enjoys upward mobility.

Wood and Wortley (2010), discuss how the likelihood of considering oneself to be Canadian is correlated with perceptions of discrimination (p.17). Their research found that the more strongly respondents agreed that their racial group was discriminated against by police, by employers or by educators, the less likely they were to think of themselves as Canadian (Ibid). Wood and Wortley (2010) conclude that usually groups perceive discrimination because discrimination exists (p.17). When considering the high percentage of newcomers living in the low-income segment of society, especially new Canadians who are categorized as racialized minorities, it seems safe to assume that discrimination is widely present in Canadian society. It is important to understand how realizing a social connectedness between neighbours and a subjective sense of belonging to a community may enhance someone's sense of feeling 
Canadian, as well as encouraging social cohesion between all Canadian residents. However, the fact that discrimination does widely exist in Canada, especially institutionalized discrimination, must be constantly brought to the surface if true social cohesion is to exist.

It is important to find ways to tap into the resources that the residential space may offer, including networks that may occur from socializing with neighbours. There is a possibility that these networks may enhance the current state of neighbourhoods by encouraging people to mobilize for things that will help the residential area. These networks may expand social capital for increased social mobility, employment or assistance with child care. A realization in social connectedness of neighbours may encourage further political participation or smoother adjustment to life in a new environment, perhaps combating loneliness, thereby enhancing many different aspects in one's life.

\section{Normalizing Effect of Green Space}

Common green spaces in residential neighborhoods have the potential to create a setting that encourages inclusion; however, in many marginalized neighborhoods this space is uncared for and is more likely to contribute to an individual's feeling of exclusion. Rishbeth and Finney (2005) discuss that how residents decide to use public green space depends on various factors. Some of these factors include convenience and the preferences and perceptions of green space developed through the course of an individual's life experience (p.282). Their research explores how urban green spaces may be accessed and enjoyed as restorative experiences for refugees and asylum seekers $(\mathrm{Ibid})$. The benefits of spaces that are green and represent nature within an urban context are seen as a positive part of life for many urbanites (Rishbeth and Finney, 2005, p.282). These benefits are both physical and psychological ( $($ bid). Physical, in that public green space 
provides an outlet for exercise. Psychological benefits are accomplished through the reduction of stress by providing places of escape and play (Ibid). Therefore, it is easy to see why maximizing the public space for wide usage is essential for the subjective integration of newcomers and the mental health of all residents in high-density, low income neighborhoods.

Relevant to the issue of psychological benefits, Rishbeth and Finney (2005) utilize Boym's (2001) perspective on how nostalgia can become restorative nostalgia (p. 289). Memories triggered by a familiar plant or a social interaction in the green spaces became a way of looking at the past and integrating this past within a new future (Ibid). These memories provided participants an opportunity to express something about their past experience of normality, relating this normality to the new context of life in which they presently find themselves (Ibid). Another benefit of the presence of plants that grow in various countries is an opportunity for delight and expertise, as someone may know about the plants from their home country, providing confidence to engage with others interested in the plant (Ibid).

An additional benefit to maintained spaces that provide multiple uses by various users, especially of beautiful gardens and plants, is that they demonstrate the possibility of a lifestyle where pleasurable aspects of life are able to be publicly valued and freely shared (Rishbeth and Finney, 2005, p. 287). The reality is that planting fancy vegetation is not the solution to solving the problems of the economically marginalized population, a great percentage of this population being new immigrants to Canada. However, inspiring a sense of communal ownership and pride over public space is a start to building networks and feeling more satisfied with life in a new country. 


\section{Case Study Area: St. James Town}

In this section, the study area will be briefly described, focusing on the physical structure of the place as well as the socio-economic and demographic conditions of the people who live there. The information used in describing St. James Town (SJT) is generated from the last two completed censuses of 2001 and 2006, as well as from the City of Toronto neighbourhood profiles that follow both mentioned census years, a study completed by the Wellesley Institute, a Metropolis working paper, my own personal observations and discussions with one of the property managers, superintendents and a few of the residents.

As mentioned in the introduction, the study area is St. James Town, located in downtown Toronto (Census Tract 0065.00). As shown in figure 1 of appendix II, St. James Town is bordered by Bloor Street in the north, Wellesley Street in the south, Parliament Street in the east and Sherbourne Street in the west. This inner city neighborhood is composed of eighteen highrise apartment buildings, primarily constructed in the 1960 s.

It is well documented that in the 1950s, the physical structure of many Canadian cities began to transform -- a dramatic change of the city form that continued through to the $1970 \mathrm{~s}$ (Jacobs, 1992; Rosa, 2006). During this time, influenced by Modernism and the visions of architects like Sigfried Giedion, city planners perceived the post war urban landscape of Toronto as a problem that could solely be solved by a dramatic refashioning (Caulfield, p. 58,1994 ). It was believed that to bring "order" and increase the "functional efficiency" of cities, the tasks of planning and designing should be left in the able hands of the ruling class, who, with the assistance of the technical elite, would produce urban spaces (Lefebvre, 2009). The opinions of the ordinary people who would actually live and use these spaces were not considered. 
Following this vision, between the 1960s and 1970s numerous elaborate high-rise residential buildings separated by green patches were built in Toronto, including SJT (Caulfield, 1994, p. 58; Jacobs, 1992).

In 1963, Meridian Developments with Belmont Construction began the development of SJT as an elaborate constellation of gigantic high rise buildings, comprised of 6000 suites, built from reinforced concrete slabs (Hanson, 1970). Upon construction, the buildings were marketed as a trendy, downtown living environment for young, childless, white-collar workers. Despite the initial success of this marketing, however, the trendy living arrangements quickly took a downturn (Caulfield, 1994, p 26). Many of the current residents express that the apartments feel unsafe and unhealthy due to poorly maintained spaces and unwelcome critters such as rats, cockroaches and bed bugs (Haque, Moriarty, Anderson, 2008). Other maintenance issues, such as housing without proper ventilation and lack of exhaust fans in kitchens, contribute to an inhospitable living environment (Ibid).

There are many features that contribute towards a negative living environment. Some of the concerns stated have been regarding internal and external building maintenance, lack of safe bicycle storage spaces, non functional local swimming pools, and the garbage disposal and collection process (Haque, Moriarty, Anderson, 2008). The limited availability and accessibility of quality, public and green spaces have also been expressed as an issue by many residents (Ibid). However, due to its close proximity to schools, community stores, public transit, and the downtown core, it is one of the most densely populated areas in Canada. Fourteen of the buildings are owned privately, while Toronto Community Housing is the proprietor of four of 
them. The buildings contain units ranging from bachelor to three-bedroom apartments (Toronto Neighborhoods, 2010; Toronto Community Housing, 2010).

\section{Socio-Economic and Demographic Conditions of the People Living in SJT}

Since the 1990s, the high-rise buildings in SJT have been mainly occupied by immigrants, the majority of whom are visible minorities. The term racialized minorities is used throughout the paper as opposed to visible minorities, however, for this section the latter term, defined as: "visible minorities as, persons, other than Aboriginal peoples, who are not Caucasian in race or non-white in color" (Statistics Canada, 2006), follows Statistics Canada's terminology. At the time of the 2006 census (Statistics Canada, 2006), sixty-four percent of the SJT population had immigrated to Canada. Sixteen percent arrived prior to 1991, another twentyfour percent arrived between 1991 and 2000, and twenty-four-percent are recent immigrants, arriving within the last five years of the census (Ibid). Seventy-four percent of SJT residents are described as visible minorities. Figure 2 (see appendix II), generated from the data in the most recent census, is a breakdown of each major visible minority group in SJT.

Figures 3,4 and 5 demonstrate the top ten counties or regions of origin of recent immigrants over the last three census years of 1996, 2001 and 2006 ("places of birth" in the 2006 census are not directly comparable with previous Census years). It is important to point out that the regions of origin of recent immigrants have shifted over the last three censuses, hinting that SJT is a neighbourhood in constant transition.

In 2001, the top five languages spoken at home, not including Canada's official languages, were the following (see Figure 6): 1) Tamil - 1135 residents (r); 2) Chinese $-680 \mathrm{r} ; 3$ ) 
Tagalog (Filipino) - 670 r; 4) Korean - 535 r; 5) Urdu - 260 r (Toronto Neighbourhood Profile $74,2010)$. In 2006 there was a shift in the top languages spoken at home, shown by the following data: 1) Tagalog -1195 r; 2) Chinese - 925 r; 3) Tamil - 800 r; 4) Korean - 335 r; 5) Russian $280 \mathrm{r}$ (Toronto Neighbourhood Profile 74, 2010). The decrease of Tamil being at spoken at home and the fact that Tagalog is spoken more in 2006 , is another strong indicator of the diversity and constant transition of the neighbourhood.

Information from the 2001 and 2006 Census demonstrates just how diverse the population is and how SJT is most likely an area where newcomers live as part of the initial period of adjustment in Canada. Regardless of the decreased Tamil population, assumed by the decrease of Tamil spoken at home (refer to Figure 6), SJT remains a neighbourhood for the earlier stages in the housing careers of newcomers.

Ensuring quality public spaces where people feel comfortable is an important factor in contributing to increased subjective integration and social cohesion between neighbours, especially in the early stages of the settlement process. The following table, generated from 2006 census data (Toronto Neighbourhood Profile 74, 2010) demonstrates that there are many youth living in these apartment buildings, including immigrant and visible minority youth who may benefit from space that encourages cohesion. The social cohesion enabled through social interactions and activities, especially ones that youth feel welcome to participate in and initiate, should benefit their subjective integration. 


\begin{tabular}{|l|l|l|}
\hline Saint James Town & Age 15-19 & Age 20-24 \\
\hline Number of youth & 725 & 1510 \\
\hline \% Immigrant youth & 62.3 & 42.6 \\
\hline \% Visible minority youth & 73.4 & 60.2 \\
\hline
\end{tabular}

Table 1: Youth living in St. James Town. From City of Toronto Neighbourhood Profile 74, 2010

SJT has a very diverse population of approximately 14600 residents, according to Statistics Canada (2006 Census); resident estimates, however, place the number at 25-30000 people, as multiple families may reside in one apartment, and are most likely not included on the lease and census data (Haque, Moriarty, Anderson, 2008). This underreporting of the actual number of individuals in the neighbourhood further emphasizes the need for better living arrangements and quality public spaces.

\section{Post-secondary Training and Low Income Cut-off}

The following statistics, explained in this section, indicate that many of SJT residents are qualified to join the creative class, or were part of the creative class previous to immigrating to Canada. Sadly, these numbers also demonstrate that SJT residents are not able to exercise or maintain a living with their creative class skill sets. It is important to discuss the statistics describing the neighbourhood's educational attainment; although many of the residents have some sort of postsecondary training, the average income is below that of the low income cut-off, due to various reasons. The low income cut-off is defined by Statistics Canada as the following, 
"An income threshold below which a family will likely devote a larger share of its income to the necessities of food, shelter and clothing than an average family would" (Statistics Canada 2010). However, Low income cut-off, has been discussed as a problematic concept, which many poverty advocates state does not equate a living wage (Richards et al, 2010). Therefore, the yearly average earnings of 18,815 dollars, for individuals in SJT over fifteen (Statistics Canada, 2006 Census) indicates an unrealistic living wage, especially when the average monthly rent paid for a one bedroom apartment is 812 dollars. The reasons explaining the number of low income wages in the neighbourhood will be mentioned only briefly due to the length and focus of the paper.

Out of the 11,955 residents who are 15 years of age or older, approximately 6610 have a postsecondary certificate, diploma or degree. However, 2715 of these certificates, diplomas and degrees were obtained inside of Canada, while 3890 were obtained outside of Canada (Statistics Canada, 2006). Some of the factors contributing to low income in this area are discrimination, lack of English language proficiency, lack of recognition of foreign credentials, difficult economic times, shifting industries and a demand for labour in low wage occupations (Alboim, 2005). The lack of recognition of foreign credentials is made apparent by the number of residents who have some sort of post secondary credentials yet remain underemployed.

Also, out of the total number of residents who are 15 years of age and over, approximately 7725 are in the labour force, 6685 of whom are employed and 840 who are unemployed - this places the employment rate at around 57.6 percent and unemployed at 10.9 percent (Statistics Canada, 2006). The following are the Greater Toronto Area (GTA) and Ontario employment and unemployment rates presented in order to understand how SJT 
compares to the GTA or all of Ontario (ON): Employment GTA ( $63.7 \%)$, Employment ON $(62.8 \%)$; Unemployment GTA (6.7\%), Unemployment ON (6.4\%) (Statistics Canada, 2006).

$35 \%$ of residents 15 and over were reported in the 2006 Census as not being in the labour force. Statistics Canada defines the following situations to be categorized as not being in the labour force, "Students, homemakers, retired workers, seasonal workers in an off season who were not looking for work and persons who cannot work due to long term disability" (Statistics Canada, 2006). Again, in order to understand how SJT compares to the GTA and ON, the following numbers indicate people not in the labour force: GTA (32\%), ON (33\%) (Ibid). This number, combined with the number of people who are unemployed, is significant when discussing the importance of functional public spaces in high-density housing areas. These numbers demonstrate that a high percentage of individuals will most likely spend a great amount of time in the residential location. The fact that the average income is below what many consider an adequate living wage - despite the fact that fifty percent of the population is employed - also demonstrates the need for accessible quality spaces that individuals can enjoy in their own neighbourhood.

\section{A Snapshot of Tamil Settlement}

Sandercock et al (2004) explain the shift in the Tamil population of St. James Town as part of four stages of Tamil migration to Canada. Tamils arriving from Sri Lanka in the two decades before the 1983 onset of civil war were mostly professionals with high education levels, often living in the UK and Africa before arriving in Canada (p.12). Although their numbers were relatively small, they continued to preserve cultural and religious traditions through their private lives while at the same time being in favour of assimilating with Canadian society (Ibid). In 1976 
the Tamil Eelam Society of Canada (TESC) was formed, which acted as a venue for various Eelam Tamils to get together for special occasions and celebrations (Ibid).

As civil war increasingly threatened the lives of Sri Lankans, more Tamils left the country as refugees, choosing Canada as a desired destination. Many of the first refugees were single, young men with limited English and education who fled to save their lives and eventually sponsor their families (Sandercock et al, 2004, p.12). A pattern was soon established of young men working multiple low-wage jobs and sharing an apartment, most often in SJT (Ibid). Many of the newcomers from this stage were put in touch with one another through the TESC (Ibid). A decade after the first wave of Tamil refugees, a strong community formed in the geographical area of SJT, so much so that it became known as "little Jaffna" (Sandercock et al, 2004, p.13). Women and families started joining these young men and "little Jaffna" emerged as small businesses were opened by Tamil entrepreneurs and for Tamil consumers (Ibid).

Many Tamils have moved out from the downtown core but still remain a predominant group of recent immigrants in the region (Sandercock et al, 2004, p.14) There was a migration to other downtown areas such as Regent Park, Parkdale and Wallace Emerson, where a Tamil housing co-op was built in 1988 by the Society for the Aid of Sri Lankan Minorities (Ibid). However, by 2003 , motivated by the need for more space and status, and more knowledgeable about Toronto's culture and landscape, the majority of the Tamil population shifted to the eastern and northern suburbs of Scarborough and North York (Sandercock et al, 2004, p.15).

Ornstein's (2000) analysis of the 1996 census identified the Tamil community as being at risk, based on poor educational and economic status, rooted in discrimination (p.5). Tyyskä (2005) demonstrates that poverty and discrimination can result in high levels of stress among 
Numerous dumpsters and recycling bins line a few of the parking lots, along with small and large pieces of rejected furniture. The apartment building on Wellesley, where the Food Basics (a grocery store) is found, is also occupied by the following: a small store selling inexpensive merchandise, a convenience store, and one store has a sign advertising the sale of spices. On the first floor of the apartment building beside the grocery store a sign in the window announces English classes. There is also a doorway in the building, close to the pool with the blasted balconies, which states that it is affiliated with the Cabbage Town Youth Centre. Close to these two buildings is a huge white canopy covering a fruit market, open in the spring, summer and fall from Thursdays to Fridays. There is also a community center with a daycare, a large kitchen facility, a few meeting rooms, a small gymnasium, some athletic equipment and a public library. A small grassy, green space surrounds the community centre on Sherbourne and Wellesleyy.

Although recent initiatives have been launched to make SJT more of a hospitable community, it is a lower-income neighbourhood and the majority of the buildings are privately owned, with profits being the main concern of the proprietor. This means that the principal way to enhance the community is through advocacy and the mobilization of the huge number of residents. Although many people are concerned with necessities and the early stages of settlement in Canadian society, it is important to continue advocating and supporting present community initiatives and members that are asking for the enhancement of quality multi-purpose public spaces, and property and building maintenance. SJT, being such a diverse community and a location of early housing for newcomers, has the potential to discover and create ways for spaces to be more inclusive and welcoming for all people residing in Canadian cities. 


\section{Research Strategy and Methodological approach}

This section will briefly focus on field research I conducted for this paper and my positionality as a researcher. Field research is, "The qualitative research process where data are collected in a naturally occurring setting" (Payne G. and Payne J., 2004, p. 94). Field research is the most appropriate strategy to utilize in gaining a clear picture of the people who live in SJT and their realities. This study aims to unearth how public spaces in a particular neighborhood are utilized by residents, and whether they foster or limit the social cohesion and belonging within the community. Therefore, observations of the physical environment as well as the interactions or lack thereof - between residents in public space are essential to comprehending how people spend their everyday in this environment. Interpretive Social Science (ISS), an approach concerned with how people interact and get along with each other (Newman, 2006, p. 87), is used for this paper. The ISS approach emphasizes meaningful social action, socially constructed meaning and empathetic understanding (Ibid).

The field research for the purposes of this paper was, "conducted as a preliminary exploration in order to develop ideas and hypotheses to be addressed in subsequent research through quantitative methods" (Payne G. and Payne J., 2004, p. 94). Observation, photographing and interception interviews were the three approaches I used in conducting field research. The inquiry of SJT and of the people who live there was conducted while working as a research assistant for a larger project, in which the questions were collaboratively designed with the primary researcher. Therefore, Appendix I contains only those questions out of the larger questionnaire that were used for this paper. 
I spent a total of nine hours at SJT between July and August. The photographs are used to document the physical characteristics of the space, and they provide a point of reference when analyzing field notes and transcripts. I conducted eight short interviews with respondents described in the table below. The questions asked pertained to the usages and design of public space inside and outside of the apartment buildings, as well as the social cohesion between residents. Since demographic information was not collected, the ages of the respondents were estimated.

The first five respondents described in Table 2 were residents intercepted in outdoor public spaces and asked to answer seven questions; each interview lasted about five minutes. It was more difficult gaining access to superintendents and property managers, as most employees are advised to follow a protocol for answering questions in an interview setting. Part of the protocol is that permission must be granted by upper property management, who are usually not in sight. However, eventually I was able to speak to one property manger and one superintendent, and both interviews lasted around fifteen minutes. The last interview was with an employee from the local community center, who at first wanted me to contact communications personnel first but agreed to immediately answer how he would design the space in SJT.

\begin{tabular}{|c|c|c|c|c|}
\hline Fesponolent & 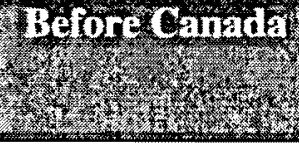 & Aprovinate & 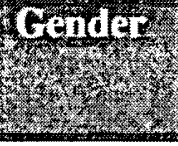 & (3) \\
\hline A & Russia $:$ & $20-30$ & $\mathrm{~F}$ & Resident \\
\hline B & Philippines & $60-70$ & $F$ & Resident \\
\hline C & Rwanda & $30-40$ & $\mathbf{F}$ & Resident \\
\hline D & Nepal & $20-30$ & $\mathbf{M}$ & Resident \\
\hline
\end{tabular}




\begin{tabular}{|c|c|c|c|c|}
\hline $\mathrm{E}$ & Bangladesh & $30-40$ & $\mathrm{M}$ & Resident \\
\hline $\mathrm{G}$ & Yugoslavia & $40-50$ & $\mathrm{M}$ & Superintendent \\
\hline $\mathrm{H}$ & Canada & $50-60$ & $\mathrm{M}$ & Building Manager \\
\hline $\mathrm{F}$ & $\begin{array}{c}\text { Question not } \\
\text { asked }\end{array}$ & $20-30$ & $\mathrm{M}$ & $\begin{array}{c}\text { Community Center } \\
\text { Employee }\end{array}$ \\
\hline
\end{tabular}

Table 2: Description of respondents in interception interviews

My positionality, defined by Valentine (2001) as, "The way in which our own experiences, beliefs, and social location affect the way we understand the world and go about researching it" (p. 345) was influenced by the following: growing up with the awareness that my family survived on my father's hourly minimum wage, generated from paycheck to paycheck, and my own experiences of apartment hunting on a tight budget, driven by the need to find a home. Tempted by cheaper rent, a downtown location and a balcony, I had previously viewed an apartment in Moss Park, a high-density neighborhood on Parliament and Queen St. East, or Toronto's Downtown East Side, which is in close proximity to the chosen site for my research topic. I am empathetic toward the families, couples or individuals who are forced to reside in these dwellings, resulting from constrained options.

My positionality as a young white female having knowledge of the Canadian system and personal connections gave me freedom in choosing another location to reside. However, I remember thinking as I looked around outside the building before viewing the apartment, "Yeah, right, I would be scared to go anywhere; no one would come visit me, what is this place?" This sentiment grew stronger as the superintendent showed me the pool and sauna, and told me never to go there alone. This reaction was possible because I knew I didn't have to live there. It is most likely that because of being an employed, single, white woman in her twenties, I had more 
accessibility to various living environments and housing options in Toronto. I was not confined by a limited option like the Moss Park dwelling. I suppose if it was my only option I would adjust and find a way to incorporate this living space into my everyday life, until it would start to feel like home. This is a tactic that many immigrants in Canada must utilize as they find themselves housed in these large, low-income, high-rise units.

\section{Research Question}

Actors from both sides of the income polarization in the global city are increasingly transnational, that is, those who have an economic advantage in the city versus those who are economically disadvantaged, and in their attempt to maintain their various agendas give meaning to and find in the city the strategic terrain for their operations. However, the terrain is not a very balanced playing field (Sassen, 2006). Bourdieu (1985) explains that each space or setting acts as a playing field, in which various people engage with one another (Ghosh, 2010, p. 4). In this field there are rules and regulations but also ways that elude them (Ibid). Ghosh (2010) explains that in order to play the game well actors must be knowledgeable of the rules, but also flexible and able to improvise when needed (p.4). It is within this playing field that tension in the usage and allocation of public space within lower income neighbourhoods may be felt. The tension arises around who has the right to decide on how the space will be used, and how much public funding will be allocated to this terrain (Marcuse, 2006). The guiding question of this major research paper is: This paper aims to examine how public space in low-income, high-density environments may be utilized to encourage social cohesion between neighbors.

The definition of public space for the purpose of the paper refers to the in-between outside space of the apartment buildings and the common areas used inside the buildings when 
tenants are not in their apartments. Due to the limited available amount of public space in lowincome, multi-ethnic, high-rise apartment neighbourhoods, it is important to explore how space is used or unused when discussing social connectedness. Public space in low-income neighbourhoods is an important resource, especially as residents normally do not have any disposable income to effectively utilize many places outside of the city or neighbourhood. St. James Town, a low-income inner-city Toronto neighbourhood, whose majority of residents are recent immigrants to Canada, will be used as a case study. The case study will explore how common spaces can be used to enhance a social connectedness between residents, leading to wider integration in Canadian society. This issue has become more prevalent as post 1970 s Canadian metropolises have seen economic restructuring, shifting immigration policies, demographic changes, and increasingly diverse immigrant flows (Murdie and Ghosh, 2010, p. 295). 


\section{Subjective Integration and the Spaces and Places of Exclusion and Inclusion}

\section{Analysis}

The freedom of mobility and the ability to choose where one wishes to go and to spend time while not working, inside or outside the home, as well as being able to create distinctive areas that suit the various social, political and cultural needs that individuals or groups may have, is a freedom that is often constrained for the poorer segments of society. Constraints are placed on economically marginalized individuals due to their limited or lack of disposable income and lack of social capital (Madanipour, 2004). Galabuzi and Teelucksingh (2010) describe social capital as the following: "Being embedded in relationships, partnerships, and networks that can be used to enhance positive outcomes, or on the negative side impede access to opportunity either through social closure or by virtue of its absence" (Galabuzi and Teelucksingh, 2010, p.6). This impediment to access causes, "exclusion from social production: denial of the opportunity to participate actively in society" (Galabuzi and Teelucksingh, 2010, p.10); racialized immigrant groups often find themselves among those who face barriers to full participation (Ibid, p.5).

The information presented in section III of this paper, generated from the last three census years of 1996, 2001 and 2006, indicates that seventy-four percent of SJT (the case study area) residents are described as visible minorities and sixty-four percent of the SJT population have immigrated to Canada (Statistics Canada, 2006 Census). Drawing conclusions from section III, the residents of SJT, a diverse, high density, economically marginalized neighborhood, are often socially, politically and culturally different from one another, yet are at the same time connected to one another and the physical environment around them as a result of their economically marginalized position in society (refer to section III, Madanipour, 2004, p. 70). 
Based on Galabuzi and Teelucksingh's (2010) description of the negative and positive sides of social capital, it should be understood that the individuals in this neighborhood are vulnerable to exclusion. Although urban centers like Toronto allow for social differentiation, it is done within a framework that also enables segregation regarding access to resources (Madanipour, 2004, p. 277).

In the case of SJT, which is a multiethnic neighborhood, there is more of an economic segregation, based on the residents' limited resources, than a marginalization of a particular ethnic group; unfortunately, however, higher concentrations of particular racialized people also tend to be more economically marginalized within Canadian society (Galabuzi and Teelucksingh, 2010). Due to the length limitations of this paper, the focus is on how marginalized space has the potential to enhance subjective integration, creating broader societal networks and contributing to a broader integration in Canadian society. Although the residents of SJT are connected by their precarious economic situations, this marginal space enables close physical contact (Madanipour, 2004, p. 277). Therefore, it is important to maximize the benefits of close physical contact through designing a hospitable environment for everyone.

As mentioned in section II, the marginalized space between the high rises of this neighborhood, and the common spaces inside the buildings, not including the residents' apartments, will be included for the purpose of this paper with what Banjeree (2001) refers to as the domain of the public sphere,. As previously stated, due to lack of disposable income and social capital, the residents of SJT often have limited choice and accessibility to the variety of spaces and places allocated for leisure and socialization, which often have member fees or user fees, in a city that utilizes Florida's (2002) creative thesis in city planning (refer to section II). 
Therefore, more importance should be placed on designing the green spaces around the highrises, and common areas inside the buildings, so that they become desirable areas for people to socialize in and spend moments of leisure time. Since these spaces, or the public sphere, are located within areas that that are mainly accessible to a local population, the interactions and activities in this space could result in creating neighborhood or community effect (Madanipour, 2004, p. 277).

The community effect is threatened when public space is seen as a space to be monitored and where it is necessary to control behaviors, rather than encouraging communication and cohesion (Ibid). The spaces around SJT are monitored by cameras, and the signs posted on the outside of the apartment buildings stating, "Vertical Neighborhood Watch", may provide a sense of security to some residents.

\section{Toronto Community Housing}

The field observations during the course of the study revealed that in the design and planning of common spaces inside and outside SJT apartment buildings, cultural differences are not acknowledged. This becomes apparent in the outside area of the public pool that is completely open so that anyone can see in to the pool area and does not offer gender specific swim times, making residents with specific religious or personal preferences/requirements feel uncomfortable (discussed further in the paper).

Although I did not discuss rules or regulations in depth with any of the interviewees, Toronto Community Housing, which owns four buildings in SJT (Toronto Neighbourhoods, 2010; Toronto Community Housing, 2010) has the following mission statement posted online: 
“...to provide affordable housing, connect tenants to services and opportunities, and work together to build healthy communities" (Toronto Community Housing, 2010). The problem, however, is that $\mathrm{TCH}$ is attempting to create communities without strategies geared to housing and immigrants. Their mandate is social housing geared to those most in need, which covers all groups. They do not prioritize specific groups, because there are so many groups, although they do provide specific programs that specific groups may use which may touch on cultural differences. However, TCH's mission statement and planning do not emphasize cultural diversity.

My analysis will not differentiate between public and private apartment complexes for the following reasons: 1) both private and publicly owned buildings surround a large outside common area in the middle of SJT that all residents have access to, and therefore, interception interviews with residents were carried out in this space; 2) interview questions did not specify if residents were from privately or publicly owned buildings; 3 ) all residents have access to the programs administered by Cabbagetown Youth Center that are held in the basement of one of the privately owned buildings.

\section{Public Space and Social Cohesion}

As mentioned in the introduction to this paper, Jenson (1998), in Galabuzi and Teelucksingh (2010), explains that social cohesion represents the following: "Absence of exclusions and marginalization, and a contrast between a sense of belonging versus isolation, participation versus non-engagement, recognition versus rejection and legitimacy versus illegitimacy" (p.2). What was observed in the outside common spaces was that there was evidence of limited social cohesion; (1) people were socializing with one another, however, 
people were in most cases socializing with individuals who reflected similar ethnic origins; and (2) parents (or individuals in caregiver positions) were usually sitting alone, and watching their children play, without much interaction between one another. As mentioned earlier (3), the public pools were used mostly by children and there was nothing in place that encouraged cultural difference. Another feature was (4) the basketball courts and playground were empty, indicating that people do not feel ownership or desire to utilize these spaces. Of course further research, if carried out in the evening, may give different results or story. Also, (5) the community centre was nearly empty, as well as (6) the daycare, although this area provides a lot of space where a variety of activities could potentially take place.

Communication between individuals may be complicated because of diversity of languages (Madanipour, 2004, p. 276). When asked if Bangladeshi and Tamil residents socialize with other renters or keep to themselves (according to the 2006 census, reported on the city of Toronto neighborhood profiles, 210 residents spoke Bengali at home while 800 residents spoke Tamil at home), a property manager from SJT responded with the following: "Often you see them speaking in their native language. That's how Canada is now. You can come on in and pretend you are in the country you came from." Although the tone of the comment was not malicious, it is an important reminder that people may perceive those who use languages that are not English or French as not embracing their new life, as pretending they are in the country they came from.

When the property manager was asked about how he would choose to design the space, he stated that he would not target the green space with any one group in mind, but appreciated people using the space as they choose. This was followed with a short anecdote about how the 
night before, ten to twelve Tamils were playing cricket in a field area behind the building, which he found "pretty cool," adding, "Whatever floats your boat." Although a perspective such as "whatever floats your boat" may indicate acceptance, the goal of social cohesion is to go beyond acceptance and for the residents of SJT to become interested in participating in social activities with one another.

When talking to a SJT superintendent, it is obvious that, although cordial with one another, there is still an "us and them" mentality between ethnic groups of residents, or a division of people. This division or creation of distrust can be destructive to one's sense of belonging. The division was made clear by a couple of observations from the interview with both the property manager and superintendent, as well as what was previously mentioned, that the people who occupied the outdoor space were usually socializing with individuals who shared similar ethnic characteristics. In order to enhance the subjective integration of newcomers, many of whom are adults; public space must be thought of in a way that suits multiple needs, attracting all sorts of people in the neighborhood.

Although the respondents' answers and the interview questions did not directly deal with pattern behavior of residents in the common spaces, the following analysis of a portion of the interview indicates the existence of a divisionary thought process. This demonstrates a need for space that encourages or allows for more exchange between residents. The superintendent, himself an immigrant who arrived in Canada in the 1990's, responded to the following question: could he think of any incidents that seemed to him like pattern behavior by Sri Lankan Tamils? Although polite in how he attempted to answer the question, there was a definite discriminatory tone; the answer was: "Not, really, sometimes their units require more maintenance. Sometimes 
they're not the cleanest. We sometimes find problems. They like humidity, this attracts cockroaches and they don't pay much attention. There's more ignorance to insect problems." This sort of thought process shows that there is a need of more understanding between people, that judging, profiling, stereotyping, and blaming is still take place.

Families with young children, a SJT property manager stated, have a harder time coming and going within the huge, old infrastructure. The difficulty in coming and going may explain why the playgrounds were empty during the periods I visited SJT in the summer. This indicates that suitable planning and enhancing the common spaces inside the building may be beneficial to encouraging higher usage and enabling social networking. The respondent mentioned that the elevators were unreliable, often breaking and not suitable for the high volume of residents who live in the buildings. Functioning elevators is something that should be addressed in order to facilitate greater mobility for people coming and going. Perhaps more emphasis could be placed on taking turns or running a program on different floors, encouraging shared responsibility of child minding, allowing mothers or caregivers of children an hour or so to participate in their choice of activity.

\section{Community Spaces}

A respondent from the SJT community centre, who also lives within the community, expressed all year access to a large indoor swimming pool as being essential to enhancing community satisfaction. Although the neighborhood has two small outdoor swimming pools, which underwent recent renovations, they are quite outdated (Wellesley Institute), and small considering the size of the St. Jamestown population. Unfortunately, an indoor pool was not included in the centre's recent renovation. The informant also added that he would like to see a 
stage, a community room or space that could be utilized for different purposes free of charge, and a job center added to the community centre, thereby bringing greater life enrichment and accessibility to resources to the neighborhood's residents.

There is currently a small community garden operated by the elementary school (Image1, below); however, usage is regulated by the school and there is a limited space and time frame of when everyone can use it. One of the issues expressed by the informants was of the limited outside space, and the need for more space. It is very evident that many people do utilize the outside space; although many changes have been made, encouraging socialization in the neighborhood, the original design of this space - including a high usage of concrete and undernourished lawn - inhibits the realization of the full potential of the area.

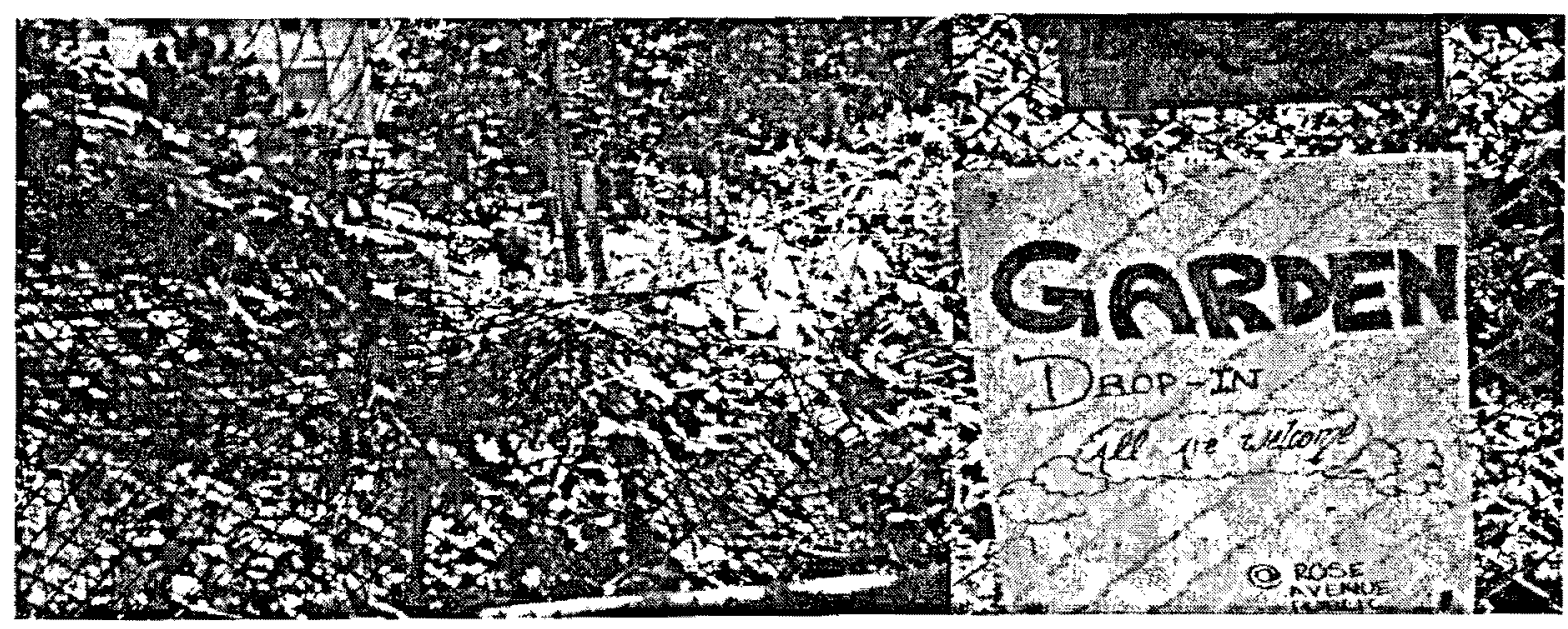

Image 1: The community garden in SJT. Photo taken by Naomi Arsenault

Inside common spaces are also often used in the colder Canadian season. One young man from Nepal said that the stairwells inside of the buildings were often used for a social space on an everyday basis in the winter. Unfortunately, as a researcher with limited experience, I did not think to ask the informant to expand on the specific activities that take place within this space. However, he did specify that these spaces were utilized because of the lack of other available 
spaces that can be used for socialization. The issue of how the winter climate places limitations on the accessibility of outside common spaces was also expressed by an elderly informant who said she spends the majority of her free time inside her apartment in the winter. She did not feel as though proper snow removal was ensured, making it hard to move around outside, and stated that she had slipped on ice the previous year, making her weary of venturing outside of the building in this season.

The Cabbagetown Youth Centre also runs a program out of one of the buildings that the residents use substantially, according to the property manager. Accompanying the residents' responses of desiring more open space was specifically greener space. The respondent from Nepal expressed his wish for a larger community garden. He stated that not many residents utilize the current garden because of time restrictions, as well as the limited space for planting. Their responses also indicated a desire for nicer parks in the area. Another informant, who was sitting on a bench alone watching her son play in the playground, said she was satisfied by the design of space and finding it convenient. However, when asked where she would like to live next, she responded High Park because there was a lot of space and it was nice and green, indicating she may have experienced a higher level of subjective integration if her first residence (SJT) in Canada had provided higher quality green spaces. Another man, who was originally from Bangladesh, sitting on the curb aligned with Wellesley St., his daughter in his arms, said he would like to make the area a little bit nicer with fancier plants.

\section{Discussion}

If the space in SJT was designed in a way that made all residents feel welcome and provided spaces for a variety of activities, subjective integration would be enhanced - in a setting 
that encourages communication and cohesion, rather than inhospitable, common spaces that are neglected and surrounded by watchful cameras. Unfortunately, my interview questions did not include a section that discussed rigid rules and regulations and how residents' cultural differences are not acknowledged. However, as Milgrom (2008) states, rules and regulations imposed on residents, especially in public housing projects, often stifle the diversity of the resident population by not acknowledging cultural differences; thereby discouraging full participation in the management of the neighborhoods they occupy (p.267). According to Rishbeth and Finney (2005), positive impressions of local environments and meaningful participation in them are a useful component of subjective integration (p.281), demonstrating the importance of public space within the context of integration and newcomers to a country.

After completion of the literature review, transcribing interviews and embarking on the analysis, I have come to the realization that a more complete understanding of social cohesion and public space would have arisen if included in the interception interviews were questions addressing the following: what are the residents' attitudes towards graffiti-are they tolerant, intolerant or indifferent? Or, how do residents feel about other residents' activities in the public spaces? The question of attitude towards graffiti is relevant due to the amount of graffiti in the outside common areas of the neighborhood. However, in many cases the spray painted messages were honorariums to SJT residents who had passed away. Therefore, where some residents may feel this type of expression deteriorates the quality of space, others may feel that it is inclusive to their pain or experiences.

Not only does the diversity of languages complicate the interactions and use of public space, but so do diverse forms of expression (Madanipour, 2004, p. 285). For instance, the 
reaction to graffiti in a public space - some view it as vandalism, while others see it as art (Ibid). It is important to strive for a way that inspires self-management by all users of space, including neutrality and flexibility in design of space that can be used for a variety of purposes (Ibid). As Murdie and Ghosh (2010) demonstrate, interacting with one another in a native language or socializing with people who share the same cultural background is not counterintuitive to integration. Speaking your original language allows people to feel more at home and relaxed, allowing for subjective integration. It is therefore important to provide space and place for people to interact as they choose. The benefit of these public spaces, if designed to allow people to use them as they choose, is that they allow for a chance to network with neighbors, whether in a native language or in encounters with residents who speak another language. It could in fact enable greater social cohesion if more adults were encouraged to use these spaces; for instance if there were all-women or male swims maybe a variety of residents would utilize the pool, facilitating networking with a wider range of neighbors.

In order for the common spaces to be used by the majority of residents in an effective manner, especially important because of the high-density in SJT and the potential to utilize and design space to encourage socialization, the planning of space must appeal to a variety of residents' needs or ideas of what common space should provide. A community centre acts as an important public space within a neighborhood like SJT, where residents are newcomers to Canada and where the majority of all residents lack disposable income. The infrastructure must be put in place so that programming is created in an inclusive manner, addressing cultural needs, preferences and differentiation in a way that allows for various users. A stage or a community room both work as neutral designs, which by simply existing may encourage a sense of 
belonging in a certain community; they may also be multipurpose, allowing at the same time for broader interactions with one another.

These spaces would enable people to meet and communicate with others, giving the public spaces and places of residence a symbolic value that could create a sense of emotional attachment to the neighborhood and city, an integral component of subjective integration (Banerjee, 2001, p.14). Taverns, beauty salons and sidewalk cafes can also be seen as public space or third spaces, a space that is not the first space of home and not the second space of work and school, but a third place of leisure and socialization (Ibid), which the public space in highrise neighborhoods should ultimately try to provide. Third space challenges binary classifications of public versus private space, enabling new ways of thinking, and new practices and identities to emerge (Valentine, 2001, p.346). Sociable pleasures can be viewed as purposeful activities. These purposeful activities can be small group rituals and social bonding through collective action (Banerjee, 2001, p.14). A community centre and community garden, for example, may be looked at as an important third space in multiethnic, low-income, high-density neighborhoods. These third spaces, in keeping with the fact that they provide attractive activities to adults, are essential in encouraging social cohesion.

A community garden can be viewed as a third space, enabling an atmosphere for socialization and leisure and very accessible to individuals with limited income (Banerjee, 2001, p.14). It also provides a cost effective solution in transforming uninspiring residential public space into an inspiring oasis. Also, different events can be easily held in such a space, which will provide the opportunity of bonding and exchange of ideas and knowledge. Another benefit to shared gardens is that of food security; although it may not fulfill all the food needs of the 
residents, a garden does provide some opportunity for cheap, nutritious options; also, if successful, it could provide produce for resale or use in other products that could be sold to generate income.

Ghosh's (2010) study, which focused particularly on high-rise apartment buildings that had a high percentage of Bangladeshi residents, explored how spaces of belonging and inclusion are created within these buildings. Ghosh (2010) found that some private residences were transformed or used for the informal economy, such as hair and beauty stylists or small food and clothing vendors. Although I did not conduct any research in the inside spaces of the SJT buildings, resulting from my own lack of accessibility - being a researcher and not a resident - it is possible that the transformation of private residence into a business of the informal economy may currently exist in SJT, and should be explored in further research.

This practice is something that could be encouraged, to create a greater variety of social places, especially for residents who do have young children and have a difficult time coming and going. The extended use of residential space facilitates a sense of community, togetherness and networking, making home into a place of refuge and comfort within the larger city (Murdie and Ghosh, 2010). With more possibility of extended, flexible space, the networks and activities may expand, enhancing the sense of community and openness between neighbors, and eventually making the whole city feel like home.

\section{Competition over Public Space}

Madanipour (2004) refers to the competition over public space in a neighbourhood as the competition for use, the display of incompatible public behaviour by individuals and groups 
(p.73). The incompatible behaviour may be negated by the participation of residents in public space maintenance. This improves the physical environment, making the environment more hospitable for everyone (Ibid). An anecdote of a deprived neighbourhood in Rotterdam provides a great example of how the participation of residents ameliorated the physical space and demonstrated a collective solidarity in their vision of community. Two women from the Rotterdam neighbourhood placed planted flowers outside of their house; the flowers were continuously being vandalized, but the women kept on replacing flowers. Within two weeks, many of the neighbours started planting flowers as a sign of solidarity in their commitment to improving the public environment of the neighbourhood (Madanipour 2004, p. 280).

As mentioned, the issue of desiring well kept green spaces did come up in the interception interviews, as well as in the Haque, Moriarty and Anderson (2008) Wellesley Institute report. In this report SJT residents vocalized that often they did not feel secure spending time in the common areas of SJT, and were discouraged by how other residents behaved, discouraging their own usage of public space. However, as the previous anecdote demonstrates, solidarity and commitment to improving the public environment of the neighbourhood by the community members may hopefully become contagious, encouraging a more inclusionary environment and therefore enhancing the subjective integration of newcomers to Canada living in SJT. 


\section{Conclusion and Suggestions for Future Usages of Public Space}

As discussed in the introduction and throughout this paper, many immigrants have chosen Canada, more specifically, Toronto, as their home. Many newcomers are attracted to Toronto because of how it is marketed as a metropolis, where city planning is guided by Florida's (2005) creative class thesis. This thesis focuses on the three T's of talent, tolerance and technology, and presents Toronto as a destination where newcomer's creative energies may flourish. However, regardless of level of education, many newcomers discover a new life where finding money for even the most basic resources is difficult, and where accessible, public or common space is limited, and in many cases neglected; the potential of their creative energies is minimized by not having opportunities to socialize and collaborate with other people, or, in keeping with the focus of this paper, their neighbours.

How to best facilitate the integration of new Canadians is a complicated question, affected by many different factors. As discussed throughout this paper, many immigrants are presently living in high density, low-income neighbourhoods with aging low quality housing. This is the result of the lack of affordable housing in Canada, particularly in Canada's major gateway cities such as Toronto, combined with the effects of income polarization, especially for many of the new Canadians labelled as visible minorities. Advocacy for ensuring affordable, suitable, quality housing for new Canadians - or, in fact, for all people living in Canada - is essential in the route to subjective, functional and civic integration. Having an adequate wage or decent job is one of the most important foundations for making the rest of life successful.

Unfortunately, the quest for affordable housing is often ignored, to the peril of many of the city's inhabitants, many being new Canadians in the early stage of settlement (Hulchanski, 2002). The quest is easily ignored when housing is left to the mercy of the market; a market 
complicated by the fact that developers have a large enough demand for expensive accommodations. However, the quest for equality or inclusion may be strengthened with quality public space. If public spaces in neighbourhoods are designed or redesigned for flexible uses, and are used for a variety of purposes, these spaces will be the most successful in encouraging social connections (Madanipour, 2004, p.284). These spaces are much more important in marginalized neighbourhoods because of the limited mobility of residents, who will therefore most likely use the spaces heavily (Ibid).

Because of the close physical contact of residents in these neighbourhood spaces, they have the potential to enhance the subjective integration of residents, especially residents who are new to life in Canada ((Madanipour, 2004, p.284). If a sense of community, belonging and membership can be created at an early stage of settlement, perhaps networks may be formed, encouraging greater functional integration in the near future, as well as a better neighbourhood and community for all residents (Ibid). Until the demand of affordable, quality housing for all residents of Canada is met, a step in the right direction would be to examine how to best utilize the common spaces available within low-income neighbourhoods.

Essential to the idea of community is that all residents feel like they belong, enjoying equal rights and access to resources that the country offers. A starting point would be access to the neighbourhood's resources. The public spaces in these neighbourhoods are one of the more accessible spaces that can be used to create a platform for social connectedness, subjective integration, greater networks and eventually functional integration. TCH administers a social investment fund that youth or immigrant groups may access for their particular cause or organization (Toronto Community Housing, 2010). The funding is for programs that impact or change behavior, knowledge and employment opportunities. The public space in SJT of both 
private and public buildings, if joined together, provides a large enough area to be creative with, if utilized properly. Perhaps funding from private owners as well as a social investment fund from TCH could be utilized to maximize the functionality of this space.

In addition to the development of a community garden, which provides a valuable, neutral public space encouraging integration and greater social cohesion in a community environment, are the following recommendations: ethical swimming pool rules and dedicated space for a variety of sports. Also the following: an outdoor oven, movie screenings, tea rooms, and market vendors will be briefly discussed as suggestion of neutral uses of space, which may enhance social cohesion, as well as subjective integration:

\section{Community Gardens}

Projects such as community gardens, as previously mentioned, enhance a neighbourhood aesthetically and provide a cheap source of food if the garden contains edible plants. Gardening may act as a therapeutic activity for people who are not working and have a considerable amount of free time. It may also provide a place to admire some of nature's wonders. Many people choosing Canada as a new home and who are starting their Canadian lives in a neighbourhood similar to SJT, may have previously had more access to a backyard or outdoor space; a community garden offers a little plot to engage with, providing a sense of familiarity in an unfamiliar place. Some residents may find the idea of a community garden unattractive, especially if there is suspicion of neighbours and a lack of desire to interact with strangers. They may feel disengaged by the idea because of the threat of vandalism and destruction of the gardens, vulnerable due to the space being outside and unguarded. However, just as the woman who continuously planted the flowers every time they were destroyed, inspiring others to follow, the users of a community garden can send a similar message. These actions of solidarity 
contribute to the strength of the community. Another advantage is the opportunity to interact with neighbours, providing a place for conversational English, if residents desire to do so, and for formations of community networks (Wakefield et al, 2007).

One of the disadvantages to a community garden in a neighbourhood such as SJT, especially if there is a strong interest in the program, is the issue of limited space (Wakefield et al, 2007). The current community garden, hosted by the Rose Avenue Public School, is quite small and, as one of the residents interviewed stated, there is a demand for a larger space, more variety and greater access. There seems to be a lot of insufficient use of space that could easily be transformed and dedicated to a garden. Community gardens are becoming more popular in urban settings, so with a neighbourhood council in place, there are different facilitators in the GTA who could assist with the development and maintenance of such a project. One such organization is The Stop Community Food Center, located in Toronto's West End (the stop, 2010).

\section{Ethical Swimming Pool Rules}

Public pools could be made into a more neutral public space for various users or potential swimmers in SJT or other low-income neighborhoods. Residents may have specific religious, cultural or personal preferences, such as not feeling comfortable swimming in an area that both sexes have access to at the same time (Boston, Meagher, 2007). It could be a more comfortable environment for people of both sexes to have female or male only swims (Ibid). There should be more of an effort placed in designating specific swimming hours, as well as creating a mechanism of coverage for the pool area, making it more secluded and private. There should also be effort placed on creating an inviting place to spend time and exercise. Different theme days may allow for various types of music to be played in the swimming area. The provision of 
childcare during various swim times may also encourage wider use. Although the two pools in SJT have undergone renovations, the majority of users and beneficiaries of any of the special programming are children. It would also contribute to a better community center, as the worker mentioned, if an indoor swimming pool was included, providing access to swimming in the winter.

\section{Dedicated Space for a Variety of Activities}

As mentioned earlier, the public space in SJT is often used for certain sport activities; an informal survey could be taken to decide which sports are popular or not so popular in the neighborhood. Perhaps the space could be better enhanced if proper game equipment were to be purchased and stored in a safe place that everyone could gain access to. This is something that could be managed by a neighborhood council made up of members of SJT residents. A youth council does currently exist in the neighborhood, who may wish to facilitate such projects $(\underline{S t}$ James. Town Youth, 2010). The money could be raised by fundraising or through donations by different service providers. The inside common space of the SJT buildings could be utilized for certain games, such as in the stairwells or the basements of the buildings.

Many of the ideas that Banerjee (2001) shares in his discussion of the future of public space can be used in the context of enhancing public space in neighborhoods like SJT to make it more neutral and conducive to social cohesion. He suggests that planners should focus on public life rather than public spaces (p.19). That conviviality, using Mlich's definition (p. 11, 1973, quoted in Banerjee, 2001, p.15), that "autonomous and creative intercourse among persons, and the intercourse of persons with their environment" should be used as a planning tool, so that communal public actions and sociable pleasures are purposeful goals (Banerjee, 2001, p.15). 
How the third space of places like coffee shops, small business and bookstores can be enhanced and created in SJT is a task that will take some commitment and much participation from the community. Third places do currently exist in SJT; it is just a question of how these can be maximized and accessible for all residents in the community.

Banerjee (2001) suggests the use of linkage fees in generating income for improving the supply of public spaces, an interesting idea that may be effective in improvement initiatives for low-income neighborhoods. Linkage fees are a requirement in many cities that demand that developers contribute a percentage of project profits toward public art (p.20), although in this case it is mostly to improve the city itself. The same sort of mechanism could be used, ensuring that some profits made from expensive condominiums in the neighborhood go into enhancing marginalized neighborhoods. Perhaps individual businesses or corporations could make donations and be recognized by a plaque. Ideally, it would be nice to have a steady supply of government funding for such projects, or a supply of suitable, quality housing and outside environment; however, this will most likely not happen anytime soon. Therefore, it is important to look for creative ways to make living arrangements more attractive and to make neighborhoods feel like home. This is currently being done even in SJT, by grassroots initiatives, and the non-profit sector (p.18); as the neighborhood grows stronger, who knows what the transformative results may be.

\section{Outdoor Oven}

Another use of space, possible in a setting like SJT, is to build a wood-fired community brick oven. This is a project that has been undertaken and quite successful at Dufferin Grove Park, in Toronto's West End. The organizers of this project have a website with many ideas and 
have also produced a booklet, also available in PDF on the website, called, "Cooking with Fire in A Public Space," (Dufferin Park, 2010). One of the oven's features is that it is possible to bake bread in it on even the coldest days of winter (Ibid). Bread is something that is made and enjoyed internationally; perhaps a schedule could be developed for baking different breads on selected weeks and days. Also, a collection of international recipes of bread baked in the neighbourhood could be produced. The oven could be used for fundraising for different organizations or groups in the neighbourhood as well for community pizza parties. The organizers of the Dufferin Grove oven found in their initial research that these communal brick ovens were used in Portugal, Italy, Poland, Trinidad, Germany, Greece, Spain and Guyana (Ibid). A communal oven encourages connectedness or belonging by providing something common and familiar. Also, the surprise of seeing something unfamiliar to many people, such as a communal oven, causes them to stop and share (lbid).

\section{Movie Screenings}

Movie nights could take the form of showing different genres of movies in a variety of languages with English subtitles, on a large screen in the community center. The films may also be shown in a designated area within the public space between buildings, or with permission by residents and weather permitting, could be projected onto the side of a building. This may encourage a place for entertainment, a third place of sorts that a variety of residents feel attracted to partake in.

\section{Tea Rooms and Markets}

Many of the hallways and stairwells are not well kept in low-income high-rise apartment buildings (Ghosh, 2010), so more emphasis must be placed on their maintenance. Also, laundry 
rooms could be enhanced with a tea or coffee area and a variety of music playing in the background, to maximize the time spent in a common area. Another idea is a farmers' market of sorts on a monthly basis, where residents can participate if they choose to. A market does currently exist but is a private business with only one vendor. These are ideas which are open to adjustment, the point being that the space does currently exist in SJT and other low-income, high-rise neighborhoods, which can be transformed and built for actual, fulfilling usages of space which enhance subjective integration and social cohesion.

\section{Looming Gentrification}

Toronto is constantly undergoing gentrification, a process where marginalized neighbourhoods attract new attention, and where public space is often viewed as underused land (as far as the capitalist market is concerned) by developers who desire to re-enter it into the market place (Madanipour 2004, p. 274). SJT and the deteriorating high-rises are prime land that will most likely be steered toward gentrification in the near future. However, as a couple of informants affiliated with the management and housing worker side of this research suggested, the idea of rejuvenating the aging housing stock and property is not problematic, it is in how the gentrification is executed and who is included in the planning and who is not. Therefore, if social cohesion can be encouraged between residents within the current public space of SJT, perhaps this solidarity and community strength can lead to greater participation and more influence in future planning. This is important because often with gentrification projects, poor neighbourhoods and the residents are as the problem instead of as a community being able to help with the development of a solution (Ibid). 
Many people choose Canada as a home, bringing with them magnificent skills, hearts, ideas and investment, all which contribute to the country. However, in a capitalist society income polarization affects many people, and most negatively those on the bottom end of the polarization. Many underemployed and unemployed immigrants face disappointment, often being stuck in large, run-down high-rises, although they make the most of their lives, striving to move forward as many human beings do. Being satisfied in your home environment, both indoors and outdoors, can provide a sense of stability and strength in a world so complicated by uncertainty. One of the ways to enhance residential life is through discovering how to best design and utilize the common areas, so that the recreational and social needs of all residents are met. 


\section{Appendix I}

\section{Questions for Key Informants/Residents}

1. Where do you and your family spend time when you're not working or not busy?

2. To what extent do you use the green spaces around your building for recreation?

3. To what extent do you use the common areas inside the building for recreation? By common areas I mean the basement or spaces that can be used by all tenants?

4. If you were in charge of designing the public spaces, what would you change or keep?

5. Considering your daily responsibilities, how much free time do you get in a week?

6. Where would you like to live next?

7. Where did you live before moving to Canada?

Questions for building managers/supervisors

1. Are there any specific incidents that you can recall that may seem to you like "pattern behaviour" of Sri Lankan Tamils living in this building?

2. How about the Bangladeshis?

3. Do you think the Tamils socialise with other renters, or do they keep to themselves?

4. Do you think the Bangladeshis socialise with other renters, or do they keep to themselves?

5. Where do you think most people spend their time- is it inside their own apartments, Or in the green spaces that surround the building?

6. Why is that the case?

7. Are there any common rooms inside this apartment building, where the residents can meet up?

8. If so, to what extent do you think the residents of this building use that space?

9. Do you encourage the residents to spend free time in the green spaces around these buildings?

10. What are some of the benefits/problems that arise from so many people sharing these spaces?

11. If it was up to you, how would you design the common or public spaces of this neighbourhood?

12. Are you an immigrant yourself?

13. Where did you come from?

\section{Question for Community Service Provider}

1. How would you design the public spaces or common spaces of this neighborhood if you were in charge of the design project? 
VIII. Appendix II

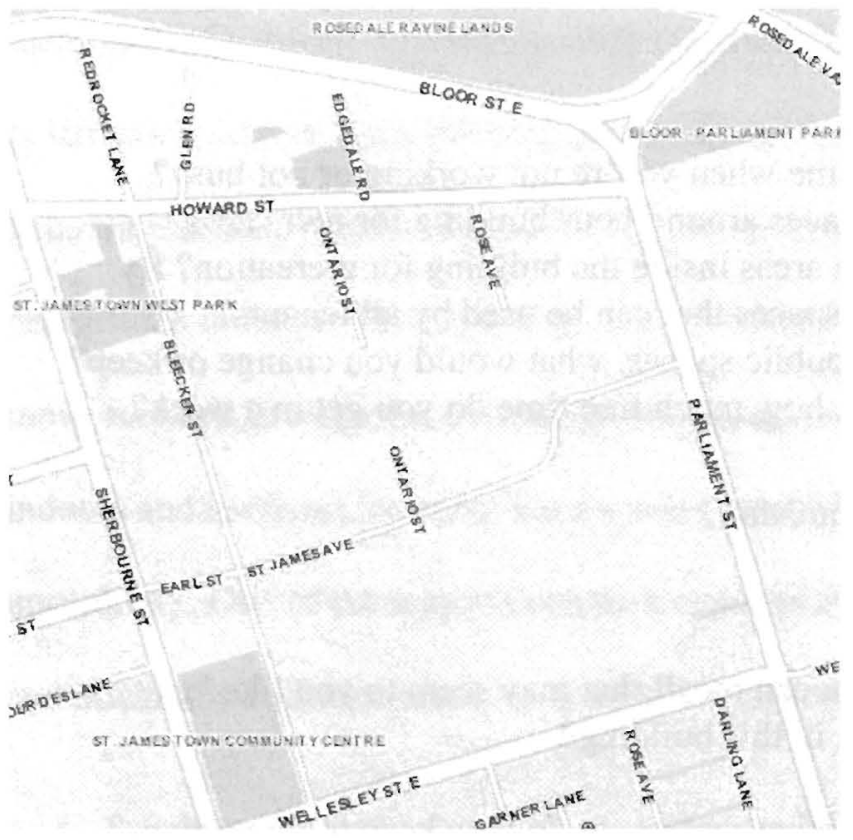

Figure 1: Area known as St. James Town, City of Toronto, www.toronto.ca/torontomaps

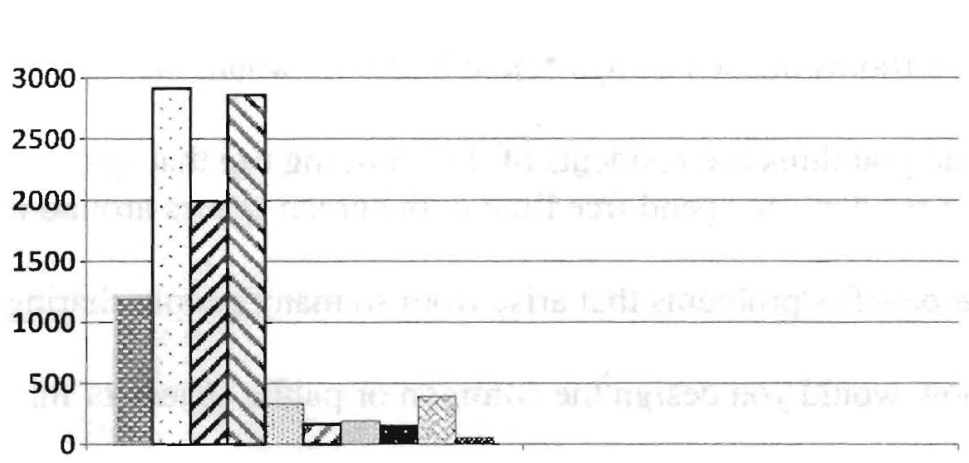

๘ Chinese

$\square$ South Asian

B Black

Gilipino

国 Latin American

Doutheast Asian

Arab

West Asian

Korean

Japanese

Figure 2: Visible minority groups, St. James Tuwn. From 2006 Census, Statistics Canada. 


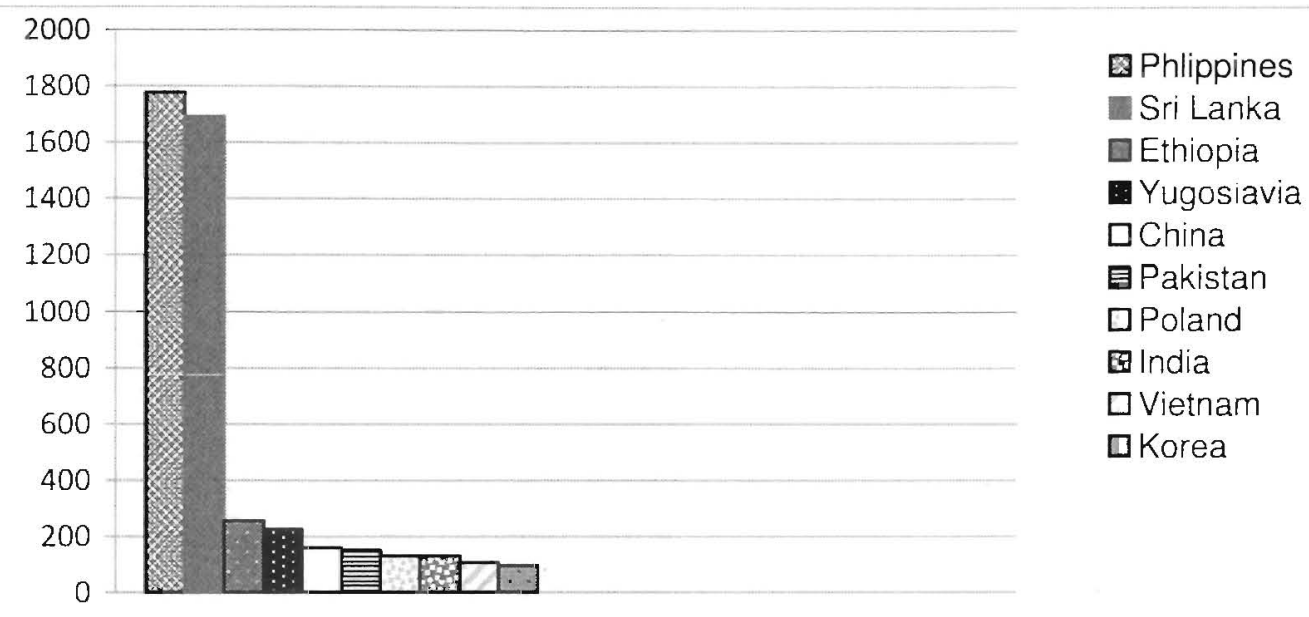

Figure 3: Top ten countries from which St. James Town residents have immigrated. From 1996 Census, Statistics Canada. Source: City of Toronto Neighborhood Profile, 2010

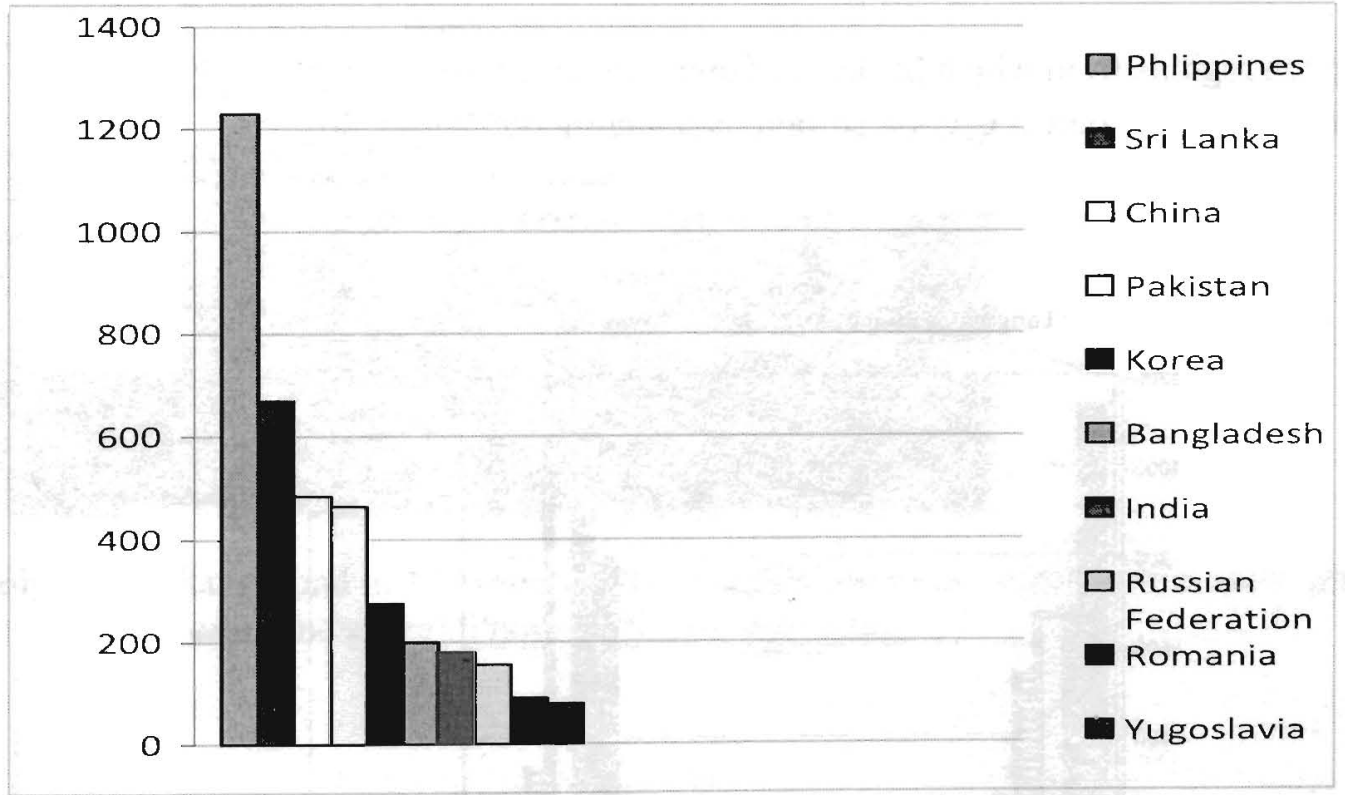

Figure 4: Top ten countries from which St. James Town residents have immigrated. From 2001 Census, Statistics Canada. Source: City of Toronto Neighbourhood Profile, 2010 


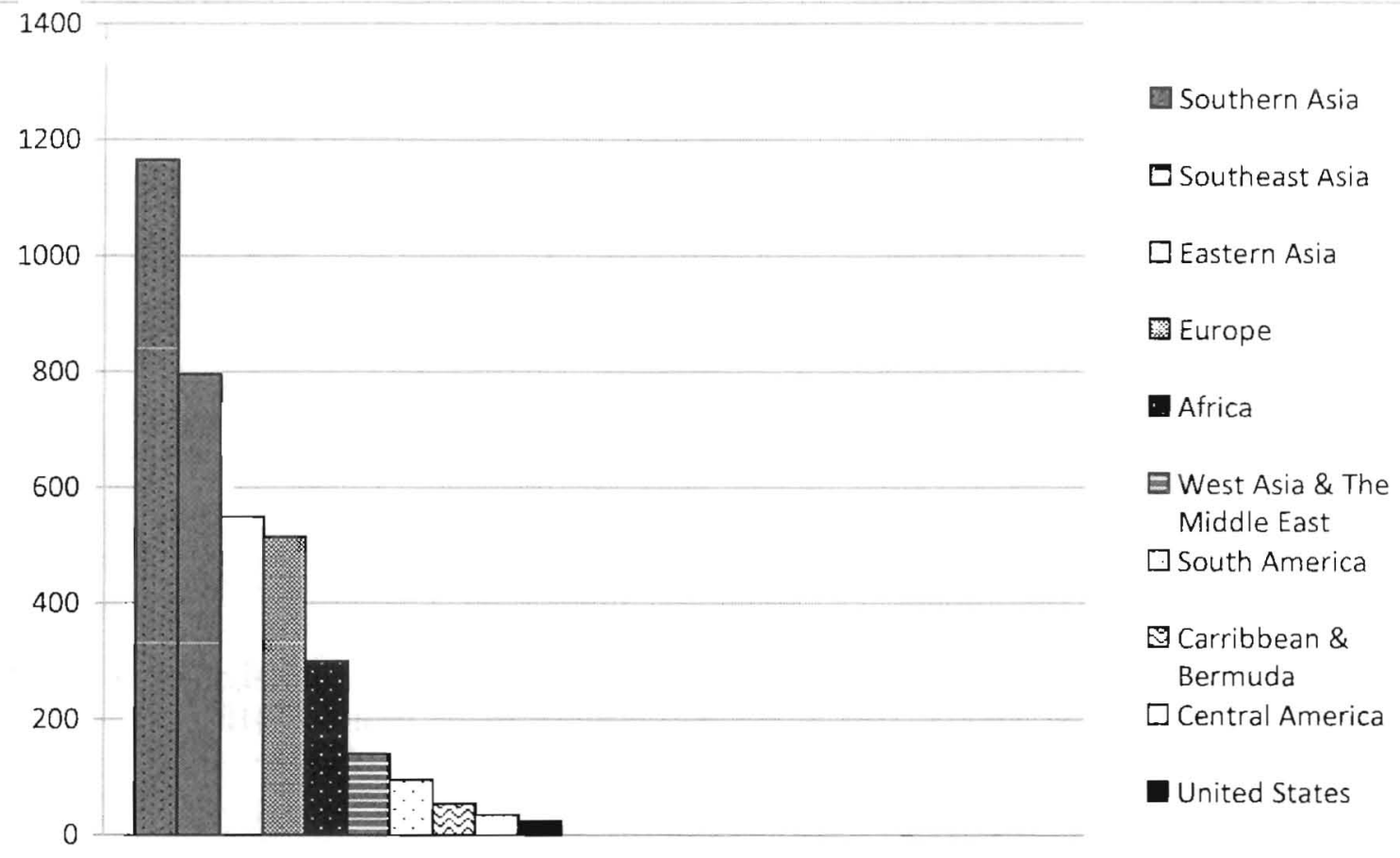

Figure 5: Top ten regions from which St. James Town residents have immigrated. From 2006 Census, Statistics Canada. Source: City of Toronto Neighborhood Profile, 2010
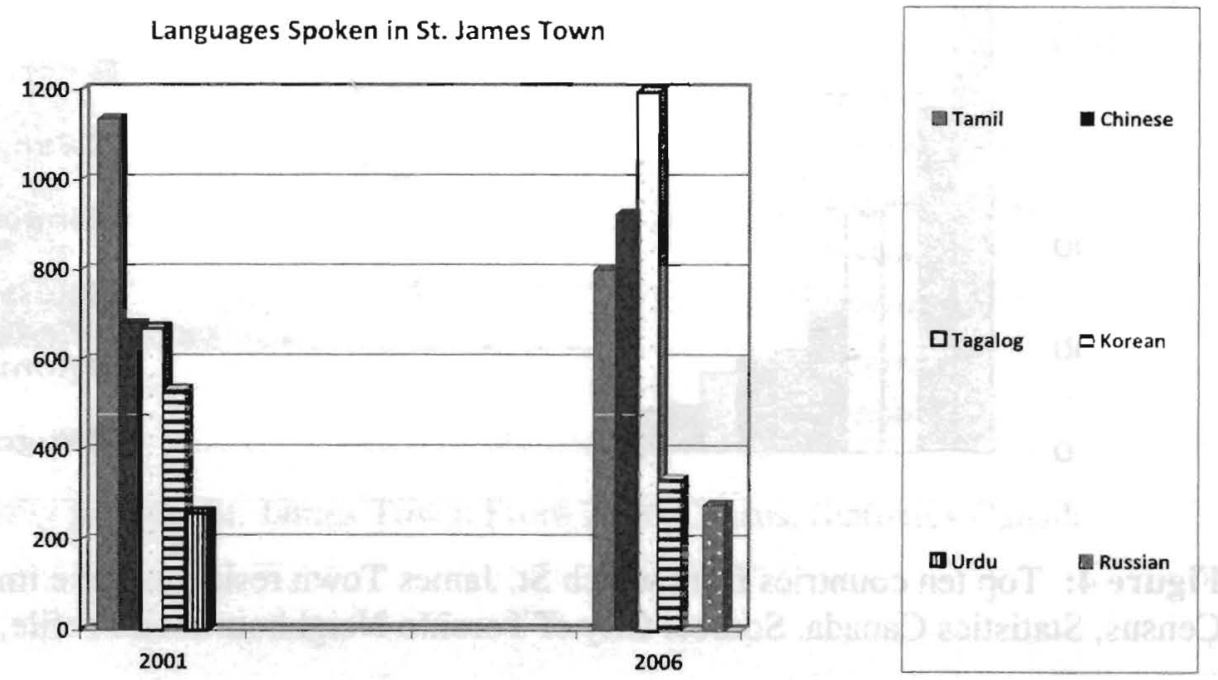

Figure 6: Top 5 languages spoken at home in St. James Town. From City of Toronto Neighbourhood Profiles, 2010 


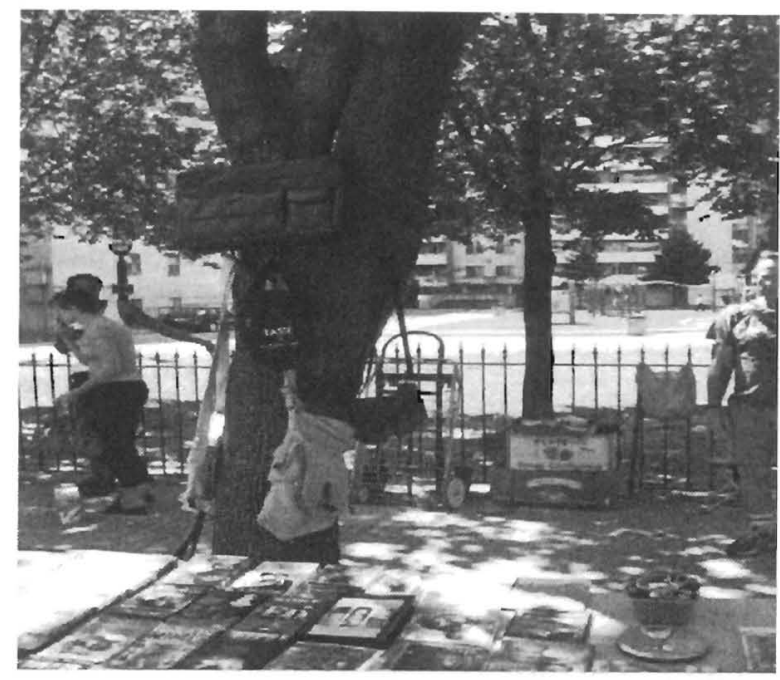

Figure 7: The public space uccupied by merchants involved in the informal economy of SJT (bordered by Wellesley in the south and Ontario in the east). Photo by Naomi Arsenault

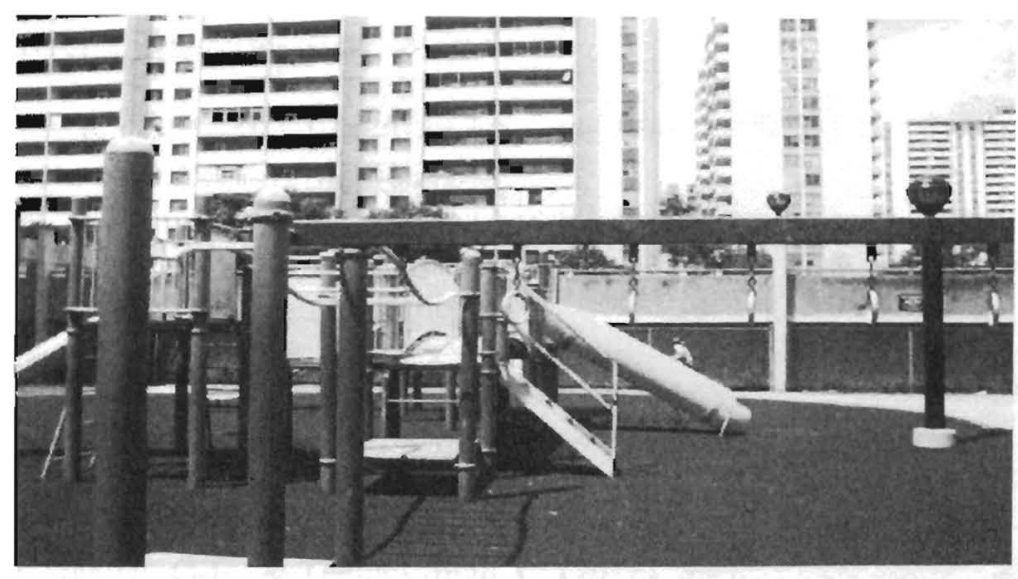

Figure 8: Playground in SJT (noteworthy that this was taken in July in the early afternoon and no one was using the space). Photo by Naomi Arsenault 


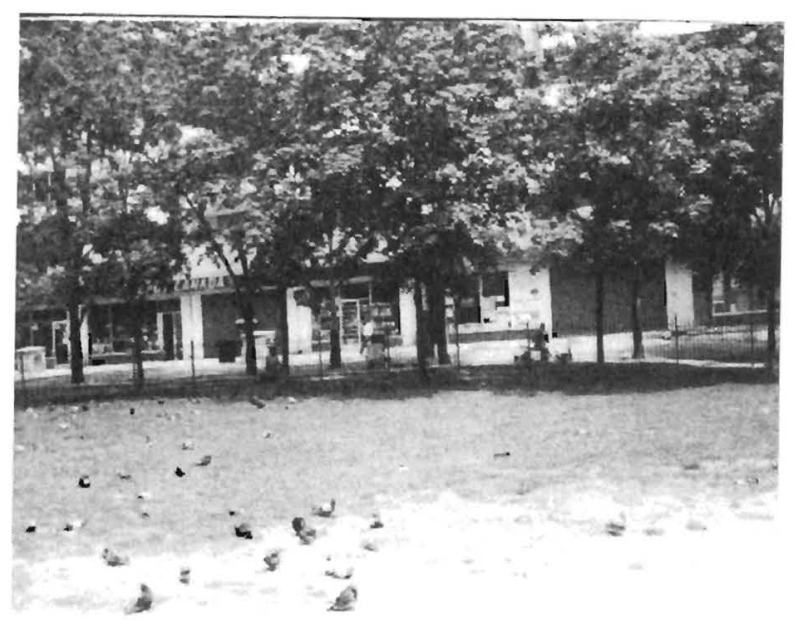

Figure 9: Empty untended green space bordered by Ontario in the east and Wellesley in the south. Photo taken in July by Naomi Arsenault 


\section{References}

Alboim, N. \& Finnie, R.Meng, R. (2005). The Discounting of Immigrants Skills in Canada. IRPP Choices. February, 11(2). www.irrpp.org.

Banerjee, T. (2001). The Future of Public Space: Beyond Invented Streets and Reinvented Places. Journal of the American Planning Association. Winter, 67(1).

Boudreau, J-A. \& Keil, R. \& Young, D. (2009).Changing Toronto: Governing Urban Neoliberalism. University of Toronto Press.

Bourdieu, P. (1985). The Social Space and the Genesis of Groups. Social Science Information. 24(2).

Boston, T. \& Meagher, S. (2007). Crescent Town Study. A final report of a study commissioned by the Crescent Town Club.

Caulfield, J. (1994). City Form and Everyday Life: Toronto's Gentrification and Critical Social Practice. Toronto. University of Toronto Press.

Dikec, M. \& Gilbert, L. (2002). Right to The City: Homage or a New Societal Ethics? Capitalism, Nature, Socialism. June 13(2): 58-74.

Florida, R. (2002). Creative Class: and How It's Transforming Work, Leisure, Community and Everyday Life. New York. Basic Books.

Florida, R. (2005). The Flight of the Creative Class: The New Global Competition for Talent. New York. HarperCollins Publishers Inc.

Friederes, J. (2008). Creating an Inclusive society: Promoting Social Integration in Canada in Biles, J. \& Meyer, B \& Frideres, J. Immigration and Integration in Canada in the Twenty first Century. Montreal\& Kingston, McGill-Queen's University Press.

Galabuzi, G-E . \& Teelucksingh, C. (2010). Social Cohesion, Social Exclusion, Social Capital. Region of Peel Discussion Paper. Published February .

Ghosh, S. (2010). Everyday Lives in Vertical Neighbourhoods: Exploring Bangladeshi Residential Spaces in Toronto.

Hanson, J.(1970). St James Town. City of Toronto, Development Department, Research and Information Division: December issue.

Harvey, D. (2003). The Right to the City. International Journal of Urban and Regional Research. December 27(4):939-41

Haque, N. \& Moriarty, E. \& Anderson, E. (2008). St. James Town Initiative Neighbourhood and Health community voices: Tackling Inequity Through a Community Based Initiative on the Social Determinants of Health. Wellesley Institute. 
Hiebert, D. (2009). Newcomers in the Canadian Housing Market: a Longitudinal Study, 2001-2005. The Canadian Geographer. 53(3):268-287.

Hulchanski, D. (2002). Housing Policy for Tomorrow's City. Discussion Paper 27. Canadian Policy Research Networks INC. www.cprn.org.

Illich, I. (1973). Tools for Conviviality. New York: Harper and Row

Israelite, N. and Herman, A. and Alim, F. and Mohamed, H. and Khan, Y. (1999). Settlement Experiences of Somali Refugee Women in Toronto. Presentation for the $7^{\text {th }}$ International Congress of Somali Studies, York University, Toronto, On. July $10^{\text {th. }}$

Jacobs, J. (1992). The Death and Life of Great American Cities. New York. Vintage books, Random House.

Lefebvre, H. (2009).Translated by Moore, G. \& Brenner, N. \& Elden, S. In State, Space, World: Selected Essays. In Brenner, N. \& Elden, S. (eds).Minneapolis. University of Minnesota Press.

Madanipour, A. (2004). Marginal Public Spaces in European Cities. Journal of Urban Design. October, 9(3): 267-286.

Marcuse, P. (2006). Space in the Globalizing City. In Brenner, N. and Keil, R. (eds.) The Global Cities Reader. New York. Routledge.

Merrifield, A. (2006). Henri Lefebvre: A critical Introduction. New York \& London. Routledge.

Midgley, J. (1999). Growth, Redistribution, and Welfare: Toward Social Investment. The Social Service Review. 73(3).

Milgrom, R. (2008). Lucien Kroll: design, difference, everyday life. In Gonnewardena, K. \& Kipfer, S. \& Milgrom, R. \& Schmid, C. (eds.) Space, Difference, Everyday Life: Reading Henri Lefebvre. New York \& London. Routledge.

Millroy, B. \& Wallace, M. (2004). Ethnoracial Diversity and planning Practices in the Greater Toronto. CERIS. Policy Matters. November (12).

Mitchell, D. (2003). The Right to the City: Social Justice and the Fight for Public Space. New York. Guilford Press.

Murdie, R. \& Ghosh, S. (2010). Does Spatial Concentration Always Mean a Lack of Integration? Exploring Ethnic Concentration and Integration in Toronto. Joumal of Ethnic Migration Studies. February 36(2): 293-311.

Neuman, W.L. (2006.) Social Research Methods: Qualitative and Quantitative Approaches6 $6^{\text {th }}$ Edition, Toronto: Pearson / Allyn and Bacon.

Ornstein, M. (2000) Ethno-Racial Inequality in the City of Toronto: an Analysis of the 1996 Census, CERIS. 
Payne, G. \& Payne, J. (2004). Key Concepts in Social Research. London. Sage Publications.

Peck, J. (2005). Struggling With the Creative Class. International Journal of Urban and Regional Research. December, 29(4): 740-770.

Qadeer, M. (2003). Ethnic Segregation in a Multicultural City: The Case of Toronto, Canada. CERIS working paper no. 28 .

Richards, T. \& Cohen, M. (2008). Working For A Living Wage: Making Paid Work Meet Basic family Needs in Metro Vancouver. Report, wwwpolicyallternatives.ca.

Rishbeth, C. \& Finney, N. (2005). Novelty and Nostalgia in Urban Green Space: Refugee Perspectives. Department of Landscape, University of Sheffield, UK.

Ronneberger, K. (2008) Henri Lefebvre and Urban Everyday Life: In Search of the Possible. In Gonnewardena, K. \& Kipfer, S. \& Milgrom, R. \& Schmid, C. (eds.) Space, Difference, Everyday Life: Reading Henri Lefebvre. New York \& London. Routledge.

Rosa, V. (2006). Producing Race, Producing Space: The Geography of Toronto's Regent Park. Thesis ,submitted Master of Arts department of Sociology and Equity Studies, Ontario Institute for Studies in Education of the University of Toronto.

Sahak, J.(2008). Race, Space and Place: Exploring Toronto's Regent Park from a Marxist Perspective , a Major Research Paper submitted in conformity with the requirements for the degree of master of Immigration and settlement Studies, Ryerson University.

Sandercock, L. \& Dickout, L. \& Winkler, R. (2004). The Quest for an Inclusive City: An Exploration of Sri Lankan Tamil experience of Integration in Toronto and Vancouver. No.04-12, Working Paper Series, Research on Immigration and Integration in the Metropolis, Vancouver Centre of Excellence.

Sassen, S. (2006). Whose City is It? In Brenner, N. and Keil, R. (eds.) The Global Cities Reader. New York. Routledge.

Tyyskä, V.(2005). Parent-Teen Relations in the Toronto Tamil Community : A Research Report, Department of Sociology, Ryerson University. Research Report for CERIS 2004 Funded Project.

Wakefield, S. and Yeudall, F. and Taron, C. and Reynolds, J. and Skinner, A. (2007) Growing Urban Health: Community Gardening in South-East Toronto. Health Promotional International, 22(2).

Valentine, G. (2001). Social Geographies: Space and Society. England. Pearson Education.

Wood, P. \& Wortley, S.(2010). Alienation: Racism, Injustice and Other Obstacles to Full Citizenship. CERIS working Paper, No. 78. 


\section{Websites}

Dufferin Park, www.dufferinpark.ca/oven/wiki/wiki.php.2010.

St James. Town, http://www.stjamestownyouth.com/, 2010.

Statistics Canada, www.statscan.gc.ca, 2010.

Toronto District School Board, www.tdsb.on.ca, 2010

The Stop, www thestop.org, 2010

Neighbourhood profiles, www.toronto.ca/deomgraphics/neighbourhoods.htm, 2010.

Toronto Community Housing, www.torontohousing.ca, 2010. 